Discussion

Papers
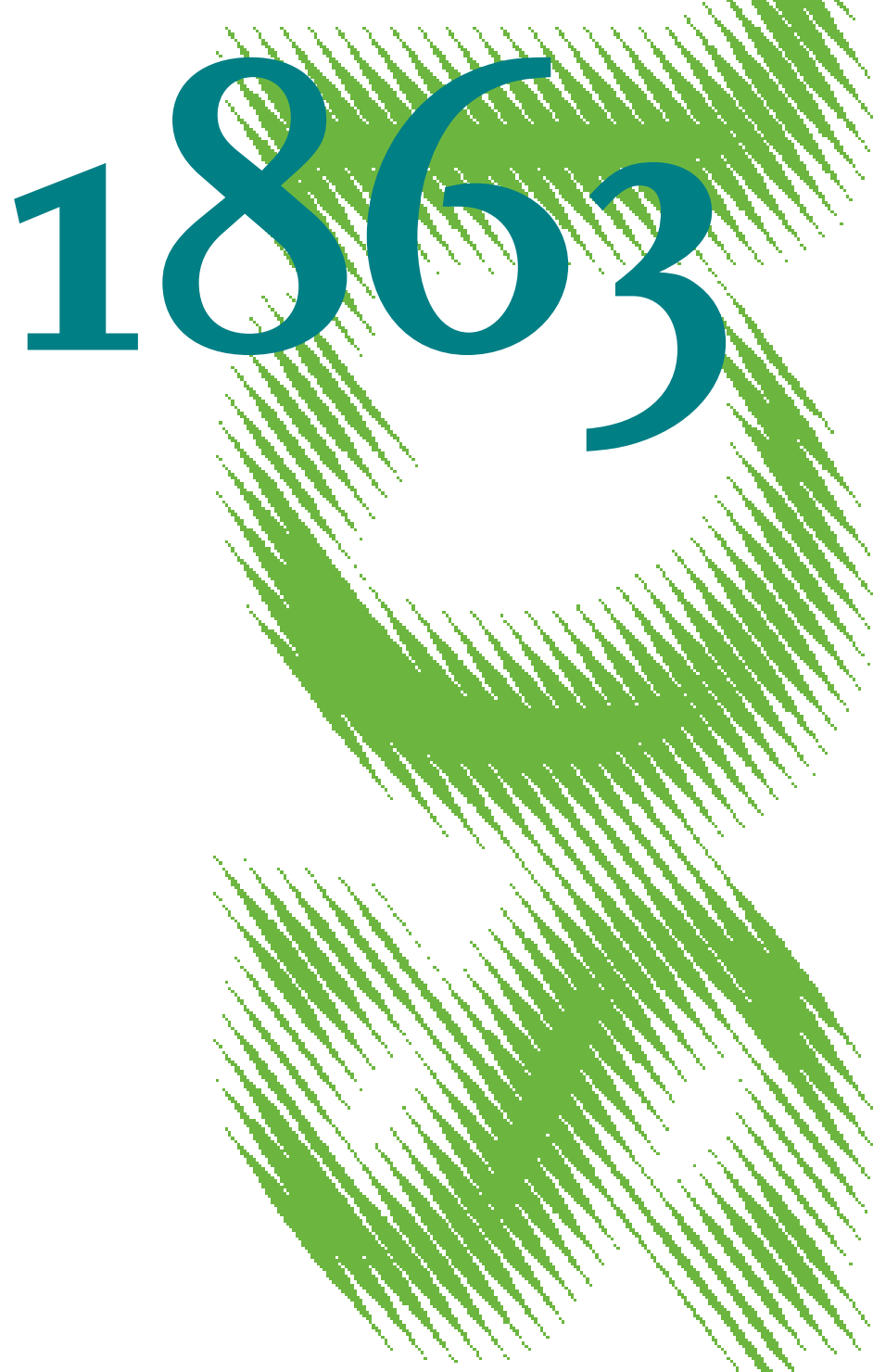

A Glimpse of Freedom: Allied Occupation and Political Resistance in East Germany 
Opinions expressed in this paper are those of the author(s) and do not necessarily reflect views of the institute.

IMPRESSUM

(C) DIW Berlin, 2020

DIW Berlin

German Institute for Economic Research

Mohrenstr. 58

10117 Berlin

Tel. +49 (30) $89789-0$

Fax +49 (30) $89789-200$

http://www.diw.de

ISSN electronic edition 1619-4535

Papers can be downloaded free of charge from the DIW Berlin website:

http://www.diw.de/discussionpapers

Discussion Papers of DIW Berlin are indexed in RePEc and SSRN:

http://ideas.repec.org/s/diw/diwwpp.html

http://www.ssrn.com/link/DIW-Berlin-German-Inst-Econ-Res.html 


\title{
A Glimpse of Freedom: Allied Occupation and Political Resistance in East Germany
}

\author{
Luis R. Martinez (P) \\ University of Chicago
}

Jonas Jessen

DIW Berlin

April 7, 2020

\author{
Guo Xu \\ UC Berkeley Haas
}

\begin{abstract}
This paper studies costly political resistance in a non-democracy. When Nazi Germany surrendered in May 1945, $40 \%$ of the designated Soviet occupation zone was initially captured by the western Allied Expeditionary Force. This occupation was short-lived: Soviet forces took over after less than two months and installed an authoritarian regime in what became the German Democratic Republic (GDR). We exploit the idiosyncratic line of contact separating Allied and Soviet troops within the GDR to show that areas briefly under Allied occupation had higher incidence of protests during the only major episode of political unrest in the GDR before its demise in 1989 - the East German Uprising of 1953. These areas also exhibited lower regime support during the last free elections in 1946. We argue that even a "glimpse of freedom" can foster civilian opposition to dictatorship.

Keywords: East Germany, political resistance, protest, autocracy, spatial RDD, World War II

JEL Classification: F51, H10, N44, P20
\end{abstract}

Email: luismartinez@uchicago.edu, jjessen@diw.de, guoxu@haas.berkeley.edu. Mariella Gonzales and Jiaqi Zhang provided excellent research assistance. We would like to thank Nico Voigtländer, Peter Buisseret, Ernesto Dal Bo, Christian Ochsner, Aleksandra Peeva, Mehdi Shadmehr, and Joachim Voth for helpful comments. We thank audiences at DIW Berlin and the Political Economy in the Chicago Area (PECA) workshop for comments and helpful suggestions. We are indebted to Holger Kern for kindly sharing data with us and with Jenns Robertson for kindly answering our questions on the THOR dataset. We gratefully acknowledge funding from the Pearson Institute for the Study and Resolution of Global Conflicts. (I) indicates that the order of authors is randomised. 


\section{Introduction}

Countries experiencing declines in civil liberties and political rights have outnumbered those with improvements for more than a decade. Over $60 \%$ of the world population lives in countries that are less than fully free (Freedom House, 2020). In many of these countries, overt political opposition carries a risk for people's freedom, integrity and lives. Canonical models of regime change predict that people's willingness to rebel increases as their expected gain from regime change becomes clearer or larger (Acemoglu and Robinson, 2005). In practice, however, people living in non-democracies often only have a vague or distorted notion of what would happen were the current regime to fall. Oneparty states, like China or Cuba, and absolute monarchies, like Saudi Arabia or Brunei, leave no formal alternative. In hybrid regimes, like Russia, Turkey or Venezuela, opposition parties and their leaders are often suppressed. Lack of clarity over the alternative to the status quo may thus play an important role in explaining (the lack of) costly political opposition in non-democracies.

In this paper, we show that even a short exposure to a more accountable form of government, with greater respect for the rule of law and individual freedoms, can increase subsequent resistance to autocratic rule. Our setting focuses on the consolidation of the German Democratic Republic (GDR), the nation that emerged from the Soviet-administered occupation zone in Germany after World War II. We examine an understudied aspect of the end of the war in Germany. At the time of the Nazi surrender, $40 \%$ of the pre-arranged Soviet occupation zone was occupied by troops from the western Allied Expeditionary Force led by the US and the UK. This Allied occupation was very short-lived and Soviet forces were in full control less than two months later. ${ }^{1}$ Over the following years, the entire Soviet-controlled area would develop into a highly authoritarian and repressive regime: the GDR, also known as East Germany.

Our empirical analysis exploits the idiosyncratic nature of the line of contact separating Allied and Soviet forces at the end of the war within East Germany. We leverage historical sources to show that the line emerged through a series of haphazard military decisions made in the very final days of the war as the Allied and Soviet armies fought their way into Germany from opposite directions. As a result, part of the area assigned for Soviet occupation remained under Allied rule for around two months before the Soviet takeover, while the rest experienced Soviet rule throughout. We conduct careful

\footnotetext{
${ }^{1}$ We use the term "Allies" throughout the paper to refer to the Western Allies, formally the Allied Expeditionary Force, comprised mostly of military units from the United States and the United Kingdom. We use the term "Grand Alliance" to refer to the larger group of countries, including the USSR, that fought against the Axis powers (Germany, Italy and Japan) in WWII.
} 
historical and archival research to reconstruct the exact line of contact at the granular municipality level (Gemeinde). We then use a spatial regression discontinuity design (RDD) to study the effects of a fleeting exposure to Allied occupation on measures of political resistance to the budding dictatorship in East Germany.

Our main outcome of interest is the incidence of protests during the 1953 uprising in the GDR. This was the only major episode of political unrest to take place in the country until the events of 1989/90 that led to democratization and German reunification. The uprising would have arguably caused the demise of the communist dictatorship in East Germany, had it not been for Soviet military intervention (Grieder, 2012). We show that municipalities that were initially occupied by Allied forces were approximately 15 percentage points (pp) more likely to experience protests during the 1953 uprising. This is a large effect, corresponding to $68 \%$ of the sample mean.

We complement the analysis by looking at an earlier, but arguably noisier set of measures of political resistance based on the 1946 state elections in the Soviet occupation zone - the last free elections to take place in East Germany until 1990. At that time, it was unclear that the Soviet zone would become a separate country and remain under strong Soviet influence. However, the local population had been exposed to the unaccountable and unruly Soviet regime for more than a year. Furthermore, the Soviets had forced the merger of the more popular Social Democratic Party (SPD) with the less popular German Communist Party (KPD) to create the Socialist Unity Party (SED). We show that the SED vote share in 1946 was 3 pp lower in the Allied-occupied area, corresponding to an $8 \%$ decrease relative to the sample mean. Voter turnout was also $1.6 \mathrm{pp}$ lower in the Allied area, indicating that exposure to Allied rule led the population to both participate less and to vote less for the SED conditional on participating.

We validate our findings with a standard battery of robustness tests. Our results hold up when including border-segment fixed effects which constrain the comparison to municipalities in direct vicinity. We consider multiple bandwidths and ensure that our results are unchanged when using an optimal bandwidth (Calonico et al., 2014). We also examine the robustness of our findings to changes in the composition of the sample. The results hold up when excluding different segments of the line of contact, different states, or municipalities directly adjacent to the line (Barreca et al., 2016).

These findings are remarkable due to the short-lived nature of the treatment. At most, the Allied occupation lasted three months and, on average, 75 days. To guide the interpretation of the results, we discuss potential mechanisms through the lens of a political agency model. One possibility is that the local population became attached to whichever side arrived there first (i.e. a "liberator effect"). However, we show that the 
SED vote share in West Berlin was 10-13 pp lower than in East Berlin, despite the former having been initially occupied by the Soviets and only later ceded to Allied control. Using data from the 1946 population census in the Soviet occupation zone (conducted nine days after the elections), we further show that differential migration and changes in economic structure across the line of contact fail to explain our findings. To examine potential persistent effects on the quality of local administrators, we collected data on more than 1,300 mayors and found that Allied-appointed mayors were swiftly replaced following the Soviet take-over. The historical record also indicates that the Soviet administration implemented the same policies after assuming full control of the occupation zone and that the local population on both sides of the line of contact experienced similar levels of misbehavior and abuse by the Soviet occupying forces. Our preferred interpretation is that the brief exposure to the Allied forces increased the salience of the counterfactual - i.e. how different things would have been had the Allies remained in control.

This paper contributes to several strands of the literature. First, we contribute to the growing empirical literature on the determinants of costly political opposition in non-democracies. A large body of work has studied the effects of access to free media or, more recently, social media (Kern and Hainmueller, 2009; Crabtree et al., 2018; Enikolopov et al., 2019; Gagliarducci et al., 2020). Other papers have focused on the impact of state repression (Bautista et al., 2019; Rozenas and Zhukov, 2020). A recent strand has also examined the role of social interactions, peer effects and habit formation in protest participation (Cantoni et al., 2019; Bursztyn et al., 2019; Stegmann, 2019). We add to this literature by showing that brief exposure to a less authoritarian form of government amid regime change has a lasting effect on costly resistance to dictatorship. ${ }^{2}$

The idea that lack of alternatives or imperfect information about them affects political behavior has a long intellectual history. In a seminal paper, Ledyard (1984) demonstrated that the paradox of voting can be resolved if there are at least two distinct candidates. Earlier, Shepsle (1972) showed that ambiguity decreases a candidate's appeal in a simple Downsian framework. Looking at contentious politics, the theory of relative deprivation developed by Gurr (1970) argues that protests are triggered by a discrepancy between the current state of affairs and a reference point, in this case people's expectations. More recently, Shadmehr and Bernhardt (2011) study collective action in an environment in which the value of regime change is not known. To the best of our knowledge, ours is the first paper to empirically study these issues.

Our results also speak to the literature on military-civilian interactions in conflict

\footnotetext{
${ }^{2}$ Our findings are consistent with previous work on the lasting effects of short canvassing interventions on beliefs and political outcomes in established democracies (Broockman and Kalla, 2016; Pons, 2018).
} 
and post-conflict settings (Berman and Matanock, 2015). Previous work has shown that hearts-and-minds strategies are more effective than overwhelming firepower in winning over the local population (Berman et al., 2011; Kocher et al., 2011; Ferwerda and Miller, 2014; Dell and Querubin, 2018). We complement this literature by showing that shortlived differences in the quality of military governance in the very early stages of postconflict reconstruction can have a lasting effect on local political attitudes. In this regard, our findings also provide evidence on the importance of initial conditions for nation-building. ${ }^{3}$

Finally, we contribute to understanding the effects of Germany's partition after World War II (Fuchs-Schündeln and Masella, 2016; Becker et al., 2020). While most work has relied on East-West comparisons between the (democratic) Federal Republic of Germany and the (autocratic) German Democratic Republic (e.g., Alesina and Fuchs-Schündeln, 2007; Laudenbach et al., 2019), our empirical strategy provides a new perspective by using the line of contact as a source of variation within the GDR. ${ }^{4}$

The remainder of the paper is organized as follows. In section 2, we provide the historical background to situate our results. In section 3 we introduce the data; section 4 discusses the spatial regression discontinuity design and section 5 presents the main results. Section 6 provides a discussion of potential mechanisms and section 7 concludes.

\section{Background}

\subsection{The End of World War II in Germany (Jan-May 1945)}

On May 7 1945, Germany surrendered to the Grand Alliance led by the United States, the United Kingdom and the Soviet Union, putting an end to World War II (WWII) in Europe. ${ }^{5}$ Preparations for the German surrender had begun months in advance, including discussions on the temporary division of the country's territory into separate occupation zones for each of the victors. The final arrangement was ratified at the Yalta Conference in February 1945, but not made public. It allocated the eastern states of Brandenburg, Mecklenburg-Vorpommern, Saxony-Anhalt, Saxony and Thuringia to the Soviet occupation zone. The German capital, Berlin, would also be divided into four

\footnotetext{
${ }^{3}$ See e.g. Svolik (2013); Alesina et al. (2019); Bazzi et al. (2019).

${ }^{4}$ An exception is Eder and Halla (2018) who document the impact of the demarcation line on longrun population dynamics at the county-level. Our analysis, focusing on shorter term political outcomes, are conducted at the granular municipality level which is more suitable for an RDD.

${ }^{5}$ This section draws largely on Ziemke (1976); MacDonald (1993); Ambrose (2000); Beevor (2002); Toland (2003); Henke (2009); Jones (2015).
} 
sectors, despite being located well within the Soviet zone.

Importantly, the decision was made to have the boundaries of the occupation zones only come into effect after the German surrender and to not allow them to interfere with ongoing military operations. As a result, the occupation zones provided little guidance on the final location of the Soviet Red Army and the Allied Expeditionary Force (AEF) when the war came to an end. On the western front, the Allies had been making progress through France and Belgium since the D-Day landing in June 1944. On the eastern front, the Red Army had been on the offensive since mid-1943. In the fall of 1944, rapid Allied advances suggested that the line of contact where Soviets and Allies would meet might be as far east as pre-war Poland, but the Soviet offensive later that year pushed it as far west as the Rhine. When the Red Army reached the river Oder at the end of January 1945, only $80 \mathrm{~km}$ away from Berlin, it seemed certain that it would be able to capture the entire Soviet zone before linking with the Allies (panel a in Figure 1).

Preparations for the capture of Berlin and bad weather would hold back the final Soviet offensive for over two months. Meanwhile, the Allies made rapid progress through western Germany, especially after capturing a bridge over the river Rhine at Remagen (480 km from Berlin) on March 7. In early April, Allied troops entered the Soviet zone in western Thuringia (panel b in Figure 1). On April 12, they reached the river Elbe near Magdeburg and the river Mulde, one of the Elbe's smaller tributaries, south of Dessau. Allied troops were roughly $100 \mathrm{~km}$ from Berlin, deep inside the Soviet zone, and Allied commanders started making preparations for the final assault on the capital.

\section{[Figure 1 here]}

The decision whether to capture Berlin fell on Allied commander Dwight Eisenhower. Eisenhower had complete authority over Allied operations and prioritized military criteria over geo-political considerations. He decided that Berlin was excessively costly and ordered his troops on April 15 to halt the advance and allow the Soviets to capture the city. ${ }^{6}$ Fearing the possibility of friendly fire as the Red Army approached, Eisenhower informed the Soviet High Command on April 21 that Allied forces would hold the north-south line formed by the rivers Elbe and Mulde all the way to the Czech border.

\footnotetext{
${ }^{6}$ Despite pressure from British Prime Minister Winston Churchill to "shake hands with the Russians as far to the east as possible" (Beevor, 2002, p.195), Eisenhower was persuaded by the high estimated casualties from capturing Berlin, given the ongoing war against Japan in the Pacific, and by the fact that further territorial gains would only be temporary. The Soviet priority of capturing Berlin also played a part in shaping the line of contact, driven by the capital's symbolic significance and by the aim to seize nuclear research facilities in the city's outskirts.
} 
The Soviet attack on Berlin had begun on April 16 (panel c in Figure 1). Over the following days, Soviet troops encircled and fought their way through the city. At the same time the Red Army resumed its westward push towards the Allies. The first contact between Allied and Soviet troops took place at Torgau on April 25, as scattered Allied patrols raced to be the first to find the Red Army (panel d in Figure 1). ${ }^{7}$ Fearing a Soviet drive into Denmark, the Allies made a last-minute change to the line of contact by crossing the Elbe into the northern state of Mecklenburg-Vorpommern in early May (panel e in Figure 1), where they would occupy positions all the way to the Baltic. ${ }^{8}$ In the final days of the war, German soldiers and civilians made a westward dash in an attempt to avoid capture by the feared Red Army, but the Allies imposed tight controls on movement across the line. ${ }^{9}$ By the time of the final German surrender on May 7 , the gap between the two armies had been all but closed (panel $f$ in Figure 1). ${ }^{10}$ But almost $40 \%$ of the Soviet occupation zone was under Allied control (Ziemke, 1976, p.300).

\subsection{American occupation of the Soviet zone (May-July 1945)}

Following the German surrender, the local population remained uncertain about the duration of foreign occupation and the final identity of the occupying force. Details on the partition of Germany only emerged by early June when the Soviet Union pressured the Allies to vacate the designated Soviet zone. ${ }^{11}$ Whether the Allies would comply was also unclear, with the British government secretly arguing against leaving before all agreements with the Soviet Union had been reached. Some rumours about an American retreat begun spreading among civilians, but even the newly-appointed civilian authorities and local military commanders were very much left in the dark.

\footnotetext{
${ }^{7}$ Those patrols only rushed forward to meet the Red Army, but the Allied forces otherwise remained at the stipulated line, about $25 \mathrm{~km}$ west of Torgau along the river Mulde.

${ }^{8}$ The Allies also moved slightly east of the Mulde in a small segment where the river bends west near the city of Chemnitz in the state of Saxony, apparently as a result of confusion among ground troops between the Zwickau Mulde and the Freiberger Mulde rivers.

${ }^{9}$ At Lüneburg Heath, the British refused to accept the partial surrender of three German armies trying to escape the Russians in Mecklenburg. At the Elbe, where many bridges were destroyed and Allied troops tightly controlled crossings, the American commander agreed to allow German soldiers to cross, but not civilians. As the Russians approached and fighting intensified, many people drowned trying to cross the river swimming or on improvised rafts.

${ }^{10}$ In Erzebirgskreis, near the Czech border, a small pocket remained accidentally unoccupied by either army until late June 1945 (Naimark, 1997). The area, uncoloured in the map, became later known as the Free Republic of Schwarzenberg. As it was initially neither Allied nor Soviet-occupied, we drop this section in the main analysis. In the appendix we show that results are robust to including it and assigning it to be Soviet-occupied, i.e. the identify of its first occupier (see Table B1 and Table B2).

${ }^{11} \mathrm{~A}$ map of the occupation zones appeared on the front page of The Times on June 7 , having been published by a Russian newspaper the day before. See Figure A.1 for excerpts of the cover.
} 
Ultimately, US President Harry Truman opted to abide by the Yalta agreement and informed the Soviet leadership on June 14 of his intention to withdraw from the Soviet zone in exchange for access to Berlin. Military commanders met in Berlin on June 29 to finalize details for the transition and agreed that the Allied forces would sequentially retreat over a four-day period, with Soviet forces following 2-3 km behind. Once this process was complete, the Allies would be allowed into West Berlin. The redeployment took place between July 1 and 5, with little forewarning to the local population. For example, British forces in Schwerin announced on June 30 that the town would be handed over to Soviet control the following day. Less than two months after the end of the war, the Soviet Union was in full control of its occupation zone.

\subsection{The 1953 Uprising}

The Soviet Military Administration in Germany (SMAD, by its German acronym) was created in June 1945 to administer the Soviet occupation zone. ${ }^{12}$ After four years of Soviet occupation, the German Democratic Republic (GDR) was born on October 1949. By then, the Soviet-backed Socialist Unity Party (SED) had fully consolidated power and the country was well on track to becoming a one-party state along the lines of the Soviet model. ${ }^{13}$ Besides the absence of competitive elections, the country increasingly resembled the Soviet police state after the creation of the secret police, known as Stasi, in 1950 (Lichter et al., 2019). Reparations to the Soviet Union, including the dismantling of factories and infrastructure across all of East Germany, crippled the economy. Hundreds of thousands of people left for West Germany each year until the inner German border was closed in 1952.

In 1952, the SED also made explicit its aim to engage in the "accelerated construction of socialism" (Grieder, 2012; Steiner, 2013). Following this announcement, the collectivization of agriculture and development of heavy industries intensified, as well as the fight against religious organizations. In May 1953, the SED increased work norms (i.e. expected output) by more than ten percent without extra compensation (Kopstein, 1996). Under Soviet pressure, it reversed course one month later on June 11, while at the same time publicly admitting to excesses and mistakes in the official party newspa-

\footnotetext{
${ }^{12}$ Matters affecting the entire country were decided by the Allied Control Council, with participation of the four victorious powers. Berlin was jointly ruled by a Kommandantura including representatives of all powers.

${ }^{13}$ Other parties were purged of opposition leaders and pressured to join a national coalition, known as the National Front (NF). The NF would present a single list of SED-vetted candidates in all pseudoelections to take place in the GDR until 1990.
} 
per Neues Deutschland. However, the tightened work norms were not modified at first, triggering a series of protests and strikes throughout the country between June 16-21.

Protests begun in East Berlin and quickly spread throughout the country. Protesters attacked SED buildings and prisons, while demanding the resignation of SED chairman and de facto dictator Walter Ulbricht. Estimates vary, but as many as 1.5 million people participated, most of them from working class backgrounds (Grieder, 2012; Steiner, 2013). After the first day, the government declared a state of emergency and the Soviet military intervened to restore order, arguably preventing the regime from collapsing (Kowalczuk, 2003). More than 6,000 people were arrested and about a dozen were killed. Repression intensified in the following months. Arrests doubled and alleged anticommunist saboteurs were seized by Soviet forces and shipped to Siberia. A series of purges within the SED tightened Ulbricht's hold on power. This was the only major episode of political unrest to take place in the GDR until the events that led to the end of the dictatorship and German reunification in 1989/90.

\section{Data and treatment assignment}

\subsection{Data sources}

Baseline characteristics. To test for the idiosyncratic nature of the line of contact, we consolidate data from existing studies. We rely on Falter and Hänisch (1990) for measures of pre-war population and electoral outcomes. Falter and Hänisch (1990) collected socioeconomic data at the county and municipality level for the German Reich between 1920-1933. The underlying data is drawn primarily from the statistical office of the Weimar Republic (Statistisches Reichsamt) and includes both electoral data and census publications. We use data on population size, labor force participation, industry structure, and religious composition from the censuses of 1925 and 1933 . We also use electoral data from the last federal elections in $1933 .{ }^{14}$

We complement the pre-war socioeconomic data with WWII measures. First, we use rich information on Allied aerial bombings collected by the Theatre History of Operations Reports (THOR). The dataset is constructed from digitized Allied mission reports, providing granular data on the location and timing of aerial bombings between 19391945. We aggregate the data and compute whether aerial bombings occurred in proximity to a given municipality. Second, we examine whether synagogues were destroyed in a given municipality during the 1938 November Pogroms. Third, we use the location

\footnotetext{
${ }^{14}$ A detailed description of the data is provided in Hänisch (1989).
} 
of all known concentration camps and compute their proximity to each municipality. ${ }^{15}$ Finally, we calculate for each municipality the geodetic distance to a range of relevant locations: Berlin, the inner German border, mineral reserves and the closest coast. ${ }^{16}$

1953 Protest data. The data on the 1953 uprisings comes from Crabtree et al. (2018), which is based on the historical compilation by Kowalczuk (2003). The data contain indicators for the occurrence of protests between June 16 and 21 in all municipalities with a population above 1,000. Of the 2,585 municipalities, 528 experienced a protest. While at a granular level, a shortcoming of the data is that it does not include the size, frequency or exact day of the protest. Our analysis is thus restricted to treating protests as a binary variable and focuses on protest incidence. We also use the Crabtree et al. (2018) measure of signal strength by the Radio in the American Sector (RIAS) for a robustness check.

1946 Electoral data. The voting data has been compiled by Falter (1997). It contains turnout and party vote shares from the state elections for all 12,090 municipalities in the Soviet occupation zone. Besides electoral outcomes, the data also includes all the available information at the municipality level from the population census conducted nine days after the elections. The census data contains information on the population (total and male), sectoral composition of the workforce and religious affiliation. We use information from the census when we explore mechanisms in section 6 .

\subsection{Reconstructing the line of contact}

To identify the line separating areas occupied by the western Allied Expeditionary Force and the Soviet Red Army, we consulted multiple historical sources. Based on these sources, we reconstructed the progress made by each army at the most fine-grained level possible (often, but not always, at the town-day level). Despite the abundant literature on the end of WWII in Europe, this information had not been previously harmonized or digitized. A detailed documentation of the establishment of the line of contact is presented in Appendix E with a full list of sources. One particularly comprehensive source was MacDonald (1993), containing detailed accounts of Allied military advances and maps tracking the front line at various locations and points in time. Also useful were the daily progress reports produced by the Supreme Headquarters Allied Expeditionary Force (SHAEF).

\footnotetext{
${ }^{15}$ The list of concentration camps stems from the Jewish Virtual Library, while that of destroyed synagogues from the Synagogue Memorial "Beit Ashkenaz".

${ }^{16}$ Data on the global distribution of mineral reserves stems from the United States Geological Survey.
} 
[Figure 2 here]

A larger part of the line of contact is defined by the rivers Elbe and Mulde. This includes the entire segment through Saxony-Anhalt, as well as part of Saxony. For areas that were not determined by this natural geographic boundary (35\% of the line), we consulted historical accounts. These include the segment through MecklenburgVorpommern that originated in the Allied dash to the Baltic and parts of Saxony where Allied officers got confused among the many small rivers or slightly deviated from Eisenhower's plan. ${ }^{17}$ Whenever historical accounts did not document the precise course of the line at the municipality level, we consulted municipality-level sources, such as local archives or municipalities' websites containing information on the identity of the initial occupying army. At the finest level, we observe 12,090 municipalities for the 1946 elections. Figure 2 shows the treatment assignment for current municipalities $(N=2,664)$.

\section{Empirical strategy}

The line of contact between Allied and Soviet forces at the end of WWII provides idiosyncratic variation in the areas exposed to Allied and Soviet occupation. We exploit this variation in the identity of the initial occupying force in a spatial regression discontinuity design (RDD). As discussed in section 2, the variation delineating the exact frontier between the two armies depended on largely idiosyncratic factors that affected (i) the particular direction and (ii) the speed at which both armies progressed. We verify below that the final line is orthogonal to local economic and political conditions.

To estimate the effect of the exposure to the Allied (relative to the Soviet) occupation on measures of subsequent political resistance, we implement a cross-sectional spatial RDD (Dell, 2010; Dell and Querubin, 2018). We estimate the following regression,

$$
y_{i}=\alpha+\beta \times \text { Allied }_{i}+f\left(\mathbf{g}_{i}\right)+\gamma^{\prime} x_{i}+\varepsilon_{i}
$$

where $y_{i}$ is an outcome of municipality $i$. Allied $i$ is a dummy that takes the value 1 if the municipality was initially occupied by the Allied forces (to be later ceded to the Soviets) and 0 if the municipality was occupied by the Soviet forces throughout.

Given the geographic pattern of the foreign occupation of Germany, a comparison between all areas occupied by the Allied vs. Soviet forces is likely to be confounded by

\footnotetext{
${ }^{17}$ As part of our robustness checks, we verify that the results hold when we exclude (i) segments of the line, (ii) entire states, or (iii) municipalities in the immediate vicinity of the line of contact.
} 
East-West baseline differences, such as distance to the inner German border, proximity to Berlin or other underlying socioeconomic differences. To obtain a valid counterfactual, the regression discontinuity design instead compares only areas in the immediate vicinity around the line of contact. Intuitively, we leverage the fact that geographic and socioeconomic characteristics are smooth (and thus comparable) around the cutoff, whereas the line of contact provides a discontinuous change in the identity of the initial occupying force. Comparing an area that happened to be just within the reach of the Allies to an area that just fell short will thus provide the causal effect of Allied occupation around the line of contact.

To implement the spatial RDD, we first restrict the sample to a narrow $50 \mathrm{~km}$ corridor along the line of contact. ${ }^{18}$ We then follow standard practice by smoothly controlling for the geographical gradient using the function $f\left(\mathbf{g}_{i}\right)$. In the most basic specification, $f\left(\mathbf{g}_{i}\right)$ controls linearly for the distance to the line of contact, but we also allow the slope to vary flexibly on either side of it. In the full specification, the vector $\mathbf{g}_{i}$ includes a more comprehensive set of covariates to control for the "smoothness" of geography: linear controls for latitude and longitude, border segment fixed effects, as well as distance to Berlin, the nearest coast and the inner border. Finally, $\mathbf{x}_{i}$ contains an additional vector of rich pre-determined socioeconomic characteristics. The full list of variables is described in the following subsection where we test for the smoothness of the baseline covariates. We cluster the standard errors at the county level. While the assignment to treatment is at the (lower) municipality level, we cluster at the county level to account for idiosyncratic correlation in the error term among municipalities located in the same county. To more conservatively account for spatial autocorrelation, we also present Conley standard errors (Conley, 1999).

\subsection{Balance around the line of contact}

Smoothness of covariates. The main identifying assumption of the spatial RDD is that the "treatment assignment" - the initial occupation by the Allied (as opposed to Soviet) forces - is as good as random around the line of contact (Imbens and Lemieux, 2008). We can test for balance of the treatment assignment on either side of the line of contact. We conduct the analysis at the municipality level whenever the data permits. This is the finest level of granularity for which data is available. Most pre-war socioeconomic indicators, however, are only available for larger municipalities with a population

\footnotetext{
${ }^{18}$ In robustness checks, we also use different bandwidths and the optimal data-driven bandwidth selection procedure developed by Calonico et al. (2014).
} 
above 2,000 (Hänisch, 1989).

Table 1 reports descriptive statistics for our dataset. In Panel A, the units of analysis are pre-war municipalities with a population above 2,000 as published by the statistical office of the Weimar Republic. In Panel B, the units of analysis are municipalities of 1946, without any size restriction. In column 1, we produce the means for each of the baseline covariates of interest for the full sample of East Germany. Column 2 reports the difference in means between Allied- and Soviet-occupied areas. We observe that the areas occupied by the Allies are significantly different from those occupied by the Soviets. For instance, Allied-occupied areas had a higher share of industrial workers in 1933, a higher KPD vote share in the 1933 elections and were also more likely to have experienced aerial bombings during WWII. Hence, a "naive" comparison between Allied- and Soviet-occupied areas in East Germany is likely to yield selection bias. In column 3, we thus provide a narrower comparison by comparing the characteristics of Allied- vs. Soviet-occupied areas along a narrow $50 \mathrm{~km}$ corridor along the line of contact. We also add the flexible forcing variable which controls for the linear distance to the line and allows the gradient to differ on either side of the cut-off, as well as the segment fixed effects (each of these segments is on average $45 \mathrm{~km}$ in length). As column 3 shows, municipalities close around the line of contact are much more comparable, with no major discontinuities in baseline characteristics. Put differently, the estimates indicate that the covariates are smoothly distributed around the cut-off, conditional on the control function.

[Table 1 here]

Manipulation around the cut-off. A second assumption of a (spatial) RDD is the absence of sorting around the cut-off. In the spatial context, municipalities, of course cannot strategically sort. But bunching in the density of municipalities may still emerge if the final line of contact was strategically drawn to include or exclude certain locations. We can assess the extent of such bunching by inspecting the distribution of municipalities around the line of contact. Appendix Figure A.2 tests the smoothness in the density of municipalities using the local-polynomial estimation proposed by Cattaneo et al. (2019). We find no evidence for a discontinuity. Overall, the balance in predetermined characteristics and the smooth distribution of observations around the cutoff assures us of the idiosyncratic nature of the line. 


\section{$5 \quad$ Main results}

\subsection{First stage: Exposure to Allied forces}

We first quantify the difference in the duration of exposure to the Allied forces along the line of contact. We make use of detailed data on the arrival dates for the Soviet Red Army and the Allied Expeditionary Force that we collected for the largest towns in East Germany. Figure 3 shows the raw means computed by $10 \mathrm{~km}$ bins in the $50 \mathrm{~km}$ corridor around the line of contact. While the Soviet-occupied areas have, of course, no exposure to Allied forces, exposure is fairly stable on the Allied-occupied side, with some variation caused by differences in the date of arrival of the Allied troops. ${ }^{19}$ Locations further west were occupied earlier, causing a more than five-day difference in exposure to Allied forces when comparing, for example, areas $50 \mathrm{~km}$ vs. $10 \mathrm{~km}$ away from the line of contact. When comparing areas just around the line of contact, we observe a difference in exposure of about 70 days.

To quantify the magnitude precisely, Table 2 uses the RDD described in section 4 . The RDD confirms that there is a discontinuous jump in exposure to the Allies at the line of contact of around 73 days. The magnitude of the estimate varies little if we simply compare means on both sides of the line of contact (column 1) or if we use a linear forcing variable that controls for the distance to the line (column 2). This magnitude remains comparable once we allow for a more flexible and richer set of forcing variables. In column 3, we flexibly fit the forcing variable on each side of the cut-off; in column 4, we divided the line into ten segments and use border segment fixed effects to further constrain the comparison to a narrow geographic area. Finally, we also include the full set of fine-grained baseline controls shown in Panel B of the balance table (column 5). Not surprisingly, given the balance of covariates, the results remain largely unchanged. We show standard errors clustered at the county (Kreis) level in parentheses and Conley standard errors in brackets. The estimates are quite precise either way and suggest that the Allied-occupied municipalities were ruled for over two months by Allied forces before the Soviet troops took over in early July 1945.

\footnotetext{
${ }^{19}$ Length of exposure is approximated using the date of arrival to the largest town in the county (Kreis) in which the municipality is located. The Allied withdrawal started on July 1 and was completed on July 5 (Henke, 2009).
} 


\subsection{Costly political opposition: the 1953 Uprising}

We now turn our attention to our main outcome of interest - the incidence of protests during the 1953 uprising. As mentioned in section 2, this was the only major nationwide episode of political unrest in the GDR until the peaceful revolution of 1989 . We investigate the relationship between Allied occupation in 1945 and the geography of this costly act of political opposition by relating protest patterns to the line of contact.

Figure 4 shows the raw probability of protests occurring in a municipality as a function of the distance to the line of contact. The sample comprises all municipalities around the $50 \mathrm{~km}$ window with a population of at least 1,000, due to data availability. ${ }^{20}$ The figure shows a sharp drop in protest incidence when we cross the line of contact from the Allied to the Soviet side: while $34 \%$ of municipalities located less than $10 \mathrm{~km}$ away from the line on the Allied side experienced protests, only $20 \%$ of municipalities on the respective Soviet side of the line did. This discontinuity is statistically significant at the $5 \%$ level $(p=0.028)$.

Table 3 reports the corresponding RDD regressions. In column 1, we report the average difference in means in protest incidence on the Allied vs. Soviet side of the line of contact for municipalities located in a $50 \mathrm{~km}$ window around the line. On average, the probability of a protest occurring is 8 percentage points (pp) higher on the Allied side than on the Soviet side. In column 2, we introduce the RDD design by adding the linear distance to the line as a forcing variable. With the forcing function $f\left(\mathbf{g}_{i}\right)$ governing the assignment to Allied or Soviet occupation, the resulting estimate reflects the causal difference at the discontinuity. As column 2 shows, the RDD estimate sees a $16.3 \mathrm{pp}$ increase in protest incidence on the Allied side.

In the remainder of the columns, we increasingly impose more flexible RDD specifications. In column 3, we allow the slope of the forcing variable to vary on either side of the cut-off; in column 4, we restrict the comparison to municipalities in close proximity by including border segment fixed effects. Finally, column 5 includes the set of finegrained baseline controls which we presented in Panel B of Table 1. As before, given the as-good-as-random assignment of the treatment conditional on distance to the line, the inclusion of these measures does not substantially alter the estimates. Overall, the RDD estimates suggest that Allied exposure caused an increase in the incidence of protests during the 1953 uprising of between 14 and $17 \mathrm{pp}$. Compared to the mean of the dependent variable $(22 \%)$, this reflects a sizeable increase. As before, we provide standard

\footnotetext{
${ }^{20}$ This corresponds to around $22 \%$ of all municipalities in East Germany and covers about $77 \%$ of the population. Importantly, the distribution does not vary along the line of contact.
} 
errors clustered by county in parentheses and Conley standard errors that account for spatial autocorrelation in brackets. Estimates are highly precise in all cases.

[Figure 4 and Table 3 here]

We conduct a range of robustness checks. A possible threat to the validity of the RDD is that the line of contact runs along the Elbe and Mulde rivers. If other factors also jump discontinuously with the river (e.g. travel costs), a valid concern is that our results are, at least in part, confounded by the presence of natural barriers. If this is a major threat, we would expect substantial heterogeneity along the line of contact. Our results, however, hold when dropping border segments one-by-one (Figure C.1); similarly, the results hold when we exclude states one-by-one (Figure C.2). Most importantly, the results are comparable when we split the samples into segments of the line that are separated by a river, around $65 \%$ of the line, and segments that are not (Figure C.3).

Our results also hold up to a class of standard RDD robustness checks, such as the use of alternative bandwidths, including the optimal bandwidth selection by Calonico et al. (2014) (Figure C.4) or the exclusion of observations in the immediate vicinity to the cut-off (i.e. donut RDD, Figure C.5). The latter addresses potential concerns about measurement error in the exact location of the line or small spill-overs across the line (i.e. Allied bridgeheads across the Elbe before Eisenhower's decision to halt the advance). Furthermore, we conducted a randomization inference exercise where we compare the actual estimated effect against the distribution of placebo effects from 10,000 arbitrary divisions of East Germany (Figure C.6). We find that our estimate is highly unlikely to have arisen by chance $(p=0.03)$, providing robust evidence that a fleeting exposure to the Allies increased political resistance against the authoritarian regime in the GDR.

\subsection{Voting outcomes: 1946 Soviet occupation zone elections}

The empirical fact that a fleeting exposure to the Allied forces for as short as 70 days can shape the geography of costly political resistance eight years later is striking. Paucity of data largely prevents us from looking at other measures of political attitudes and behaviors in the years in-between. However, we can corroborate our results by examining the outcome of the elections of 1946, which were administered across the entire Soviet occupation zone 16 months after the Allied withdrawal. These were the last free elections to take place in East Germany until 1990, making party vote shares meaningful measures of voters' preferences. The main caveat is that at the time it was not at all clear that 
the Soviet occupation zone would turn into a separate country with a one-party state, which arguably dampens the effect of exposure to Allied occupation. ${ }^{21}$

The SMAD legalized anti-fascist political parties in the Soviet zone in June 1945, and the Potsdam agreement signed in August 1945 bolstered the return to democracy by calling for the re-establishment of local elections. Assembly elections at the municipal, county and state level were held in the Soviet zone in the fall of 1946. These elections featured the Soviet-backed SED party competing against two center/liberal parties, CDU and LDP. Following electoral setbacks in Austria and Hungary, the SMAD had forced a merger of the German Communist Party (KPD) with the more popular Social Democratic Party (SPD), thereby creating the SED. The SMAD provided the SED with resources for campaigning, censored publications of the opposition parties and also barred their candidates from running in many local races (Buckow, 2003; Falter and Weins, 2013; Stivers and Carter, 2017). Voters, however, were able to cast their ballots largely uncoerced (Braun, 1993). ${ }^{22}$ Voting against the SED can thus be viewed as another (less costly) measure of political resistance to the budding authoritarian regime.

Our analysis focuses on the state-level elections that took place on October 20 as these featured all parties and have more complete data. ${ }^{23}$ Overall, the SED fell short of a majority in the state elections (47.5\%) and received less votes than the liberal parties combined, perhaps due to the heavy-handed Soviet backing. As Grieder (2012) concludes, "the SED's support base declined precipitously once it became perceived as the Russian party" (p. 26). We investigate how support for the SED at the state elections relates to the exposure to initial Allied occupation.

Table 4 shows estimates from our spatial RDD design using the municipality-level SED vote share in the corresponding 1946 state election as the dependent variable. To ensure comparability with the previous analysis, we first present results for the sample of municipalities with at least 1,000 inhabitants before moving to the full sample. The simple RDD using a linear forcing function is presented in column 1 . While noisy and statistically insignificant, the point estimate indicates that the SED vote share was 3.2 percentage points (pp) lower in municipalities that were initially occupied by the Allies. In column 2, we allow for a richer functional form of the forcing variable by allowing

\footnotetext{
${ }^{21}$ SMAD allowed for a competitive election to take place and publicly supported a "united, democratic and peace-loving German state" (Grieder, 2012, p.20). The SED claimed in its foundational proclamation that "it would be wrong to force the Soviet system on Germany" (Bruce, 2003, p.23).

${ }^{22}$ In Berlin, the results were in line with a series of US-run opinion polls from the previous months, consistent with the absence of large-scale fraud (Stivers and Carter, 2017).

${ }^{23}$ Municipal elections took place in September 1946, and county-level elections on October 20, but the data was not fully preserved and is incomplete (Falter and Weins, 2013).
} 
the SED vote share to vary differentially with the running variable on either side of the cut-off. Areas exposed to the Allied forces exhibit a lower SED vote share, which is now precisely estimated. In column 3, we expand the analysis to the full sample of municipalities. Results remain comparable, though imprecise. Precision improves in column 4 after we include border segment fixed effects, thereby ensuring that we only compare municipalities in near proximity on both sides of the line. The inclusion of a rich set of baseline covariates in column 5 does not substantially affect the results. Similar to our initial estimates in column 1, this richer specification with a larger sample yields a 3 pp lower SED vote share in the Allied-occupied municipalities. This effect is equivalent to $7.6 \%$ of the average SED share in the sample.

The previous results indicate that initial exposure to Allied occupation reduced popular support for the Soviet administration in East Germany and for the party it backed. However, Soviet interference in the election and its lopsided policies favoring the SED may have led some voters to consider the elections illegitimate and to disengage (Croke et al., 2016). Voter abstention can thus be seen as another measure of opposition against the Soviet administration. To investigate this possibility, in column 6 we use voter turnout as the dependent variable. Turnout was quite high in this election, with only $6.3 \%$ of voters in our sample municipalities abstaining on average. Yet, column 6 shows that this share was $1.6 \mathrm{pp}$ larger on the Allied-occupied side. This effect corresponds to $25 \%$ of the sample mean of the share of voters abstaining, but it is only half as large as the effect on the SED vote share. ${ }^{24}$ Finally, we study the share of invalid votes as a third measure of regime opposition (column 7), but do not see any marked differences across the line of contact. ${ }^{25}$

In Appendix D, we conduct the same range of robustness checks as for the protest outcome. The coefficients are largely robust to the exclusion of any one border segment (Figure D.1), or any one state (Figure D.2) except for Saxony in the case of voter turnout. For both outcomes, we find that the results are driven by the segment of the line of contact corresponding to rivers (Figure D.3). The coefficients are also robust to the choice of bandwidth (Figure D.4) and to dropping municipalities close to the cut-off (Figure D.5). Randomization inference yields $p$-values of 0.09 for voter turnout and 0.12 for the SED vote share (Figure D.6).

\footnotetext{
${ }^{24}$ Both turnout and the SED vote share are measured relative to the number of eligible voters, allowing for comparison of the estimates for both outcomes. This way, we also ensure that the SED vote share is not affected by differences in turnout.

${ }^{25}$ In the municipal elections the share of invalid votes was higher and seen as a protest against the limited set of participating parties (Falter and Weins, 2013).
} 


\section{Discussion}

The fact that fleeting differences in initial conditions can shape costly political behavior in a newly emerging nation state is striking. In the previous section, we showed that roughly 70 days of exposure to Allied forces (namely US and British) caused an increase in voting and protests against the budding dictatorship propped by the Soviet occupying forces in East Germany. Our reduced-form estimates, however, arguably correspond to a bundle of different "treatments" that distinguish municipalities on opposite sides of the line of contact. In this section, we explore several potential mechanisms that may be driving the previous results and provide historical and statistical evidence to try to (at least partially) adjudicate between them.

To guide the interpretation of the results, we introduce a simple conceptual framework. $^{26}$ Consider an agent with characteristics $\mathbf{x}$ who faces a choice over two political regimes. For concreteness, let $i=s$ denote the Soviet regime, while $i=a$ denotes the Allied regime. Regimes differ in their quality, $\theta_{i}$, and the agent cares about the quality of the ruling regime. With all of East Germany under Soviet control, the quality of the incumbent Soviet regime $\theta_{s}$ is common knowledge. In contrast, the quality of the alternative - the Allied regime - is unobserved. An agent will thus only support the Soviet regime if the benefits from doing so exceed the expected benefits of the Allied regime,

$$
\theta_{s} \geq E\left[\theta_{a} \mid \mathbf{x}\right]
$$

We use this framework to characterize several potential mechanisms. First, we consider a possible "liberator effect" by which the local population rewarded whichever incoming army defeated the Nazis in their locality. Second, we consider possible differential migration across the line of contact. Third, we examine whether there were any differences in policies across the line of contact. Policy differences may arise for multiple reasons: the Allied occupation, despite being very short, could have allowed for policies causing persistent benefits to the local population; similarly, the Allies could have developed clandestine resistance networks during their brief occupation which later facilitated mobilization against the dictatorship; Soviet policies could have also differed after the Allies withdrew and the Red Army was in control of the entirety of the Soviet occupation zone. Finally, we consider our most preferred interpretation: that Allied occupation provided the local population with a clearer sense of the alternative to the Soviet regime and increased the salience of the political and institutional dilemma that

\footnotetext{
${ }^{26}$ This simple model falls under the general class of models of political agency (see Ashworth, 2012).
} 
East Germans faced.

\subsection{The "liberator effect" - within Berlin variation}

One explanation for the increased opposition to the SED dictatorship in the Alliedoccupied area is that residents of this area were grateful to Allied rather than Soviet forces for dislodging the Nazis. In this case, Allied liberation leads to a higher posterior belief about the quality of the Allied regime, tilting the balance of popular support against the Soviets (i.e. $E\left[\theta_{a} \mid \mathbf{x}\right]<\theta_{s}<E\left[\theta_{a} \mid \mathbf{x}\right.$, liberation]). However, if the identity of the liberator is the key determinant of political preferences, we would expect to see no difference in support for the Allied regime between Soviet-controlled East Berlin and Allied-controlled West Berlin, as the entire city was liberated by the Soviets.

The Berlin state election was held on October 20 1946, the same day as the elections in the Soviet occupation zone studied in subsection 5.3, and would be the last citywide election to take place before German reunification. A distinguishing feature was that the SPD was allowed to run separately from the SED, with the former going on to win the election with a resounding $48.7 \%$ of the votes. ${ }^{27}$ For this part of the analysis, we collected electoral statistics for Berlin to construct a balanced panel at the district-election level. ${ }^{28}$ The dataset covers 68 districts (33 in West Berlin ceded to Allied control in July 1945) over four elections: 1929 municipal elections, 1930 and 1932 federal elections, plus the 1946 state election. ${ }^{29}$ To study the effect of Soviet liberation on electoral support for the SED in 1946, we implement a difference-in-differences (DiD) design comparing the difference in SED vote share between East and West Berlin before and after WWII. Since the SPD participated in the 1946 Berlin election, we use the KPD vote share in the pre-war elections as the relevant comparable measure to the SED vote share in 1946. Our DiD specification includes district and year (election) fixed effects.

Columns 1-3 in Table 5 show results of a simple comparison of means between West and East Berlin in 1946. In column 2, which controls for latitude and longitude to capture potential geographic gradients in political preferences, we precisely estimate that the SED vote share is 13.6 percentage points (pp) lower in West Berlin. Further restricting the sample to the common longitude support has a negligible impact (column

\footnotetext{
${ }^{27}$ When the SMAD created the SED through the forced merger of the SPD with the KPD, the Allied administration in Berlin demanded a referendum for the merger to be valid. After $82 \%$ of SPD members voted against the merger, party dissidents were able to field their own candidates under the SPD banner in Berlin (Braun, 1993; Stivers and Carter, 2017). The election outcome was a huge disappointment for the SED, which came in third (behind CDU) with $19.8 \%$ of the votes (29.8\% in East Berlin).

${ }^{28}$ The data can be accessed at https://www.wahlen-berlin.de/Historie/wahldatenbank/wahldb0.asp

${ }^{29}$ The dataset also covers five later elections in 1948-1963, but these are restricted to West Berlin.
} 
3). Column 4 provides the DiD estimates. We find that the SED vote share differentially drops by $10.4 \mathrm{pp}$ in West Berlin in 1946. This estimate is also very precise and it is statistically significant at the $1 \%$ level. Column 5 provides disaggregate estimates for all elections, leaving 1929 as the omitted category. Figure 5 provides a visualization of these results. The difference in the KPD (SED) vote share between West and East Berlin remained fairly constant in 1930 and 1932, relative to 1929 (omitted category). This lends credibility to the identifying assumption of parallel trends underlying the DiD research design. In 1946, however, we observe a large 10.5 pp drop in the SED vote share in Allied-controlled West Berlin, almost identical in magnitude to the baseline estimate in column 4. This pattern is robust and also holds when we again restrict the sample to districts with a common longitudinal support (column 6).

[Table 5 and Figure 5 here]

In sum, the evidence for Berlin shows that support for the SED was in fact lower in West Berlin than in East Berlin in 1946, despite Berlin having been captured in its entirety by the Red Army. This result is inconsistent with a "liberator effect" leading East Germans to reward whichever army arrived first to free them from Nazi tyranny.

\subsection{Selective migration}

Differences in the characteristics of the civilian population driven by selective migration across the line of contact could also help explain our findings (Eder and Halla, 2018). Table 1 showed that the two sides of the line were highly comparable in their demographic, geographic and political characteristics in the 1920s and 30s, as well as in the impact of the Nazi regime and WWII. However, differential migration to the Allied-occupied area in the immediate aftermath of the war may have led to a disproportionate concentration of opponents to the Soviet regime on that side of the line. In terms of our model, this explanation corresponds to a case in which people with more positive priors over the Allied regime's quality self-selected into the Allied side (i.e. $\left.E\left[\theta_{a} \mid \mathbf{x}_{a}\right]>E\left[\theta_{a} \mid \mathbf{x}_{s}\right]\right){ }^{30}$

Years of exposure to Nazi propaganda and rumours of atrocities committed by the approaching Red Army generated a strong preference for Allied occupation as the war came to an end in Germany (Naimark, 1997). ${ }^{31}$ Beevor (2002) claims that in Berlin "optimists were learning English and pessimists learning Russian" (p.190). Hence, it is

\footnotetext{
${ }^{30}$ Relatedly, Ochsner and Roesel (2020) show that areas in Austria that experienced an influx of former Nazis after WWII have higher far-right vote shares up to the present day.

${ }^{31}$ The German word "Russenangst" describes this feeling of generalized fear of the Russians.
} 
certainly plausible that the Allied-occupied area within East Germany saw a substantial inflow of potential opponents of the Soviet regime. These flows had two possible sources. First, a large wave of migrants that fled westward during the Soviet invasion of Germany in the final months of the war, mostly from the eastern provinces of Silesia, Pomerania and Prussia. Second, more selective cases of migration to the Allied sector during the initial occupation after the end of the war. ${ }^{32}$

Theoretically, a migration-based explanation faces several challenges. Migration from the eastern provinces begun during the Soviet winter offensive in late 1944 and peaked in early 1945..$^{33}$ At the time, the Allies were hundreds of kilometers away, the division of Germany into occupation zones remained confidential and the location of the line of contact was highly uncertain. Hence, war-induced migration across the line of contact within East Germany could only be quantitatively meaningful in the final days of the war when the Allies were awaiting the Soviets. At that time, however, transportation was completely disrupted and Allied troops restricted civilian crossings (MacDonald, 1993). More importantly, between the end of the war and the militarization of the inner border in 1952, anyone wanting to escape from Soviet rule could easily do so either by crossing into the American or British occupation zones, or into West Berlin. ${ }^{34}$

Empirically, we can examine the evidence in support of a migration-based mechanism using data from the 1946 population census, carried out just nine days after the elections in the Soviet occupation zone. To start with, aggregate statistics show that cross-state migration was relatively low: $74 \%$ of people lived in the same state as in 1939 . Refugees from the eastern provinces represented $13 \%$ of the total population and a further $8 \%$ were foreign nationals (mostly resettled Germans from Eastern Europe). ${ }^{35}$

Importantly for our RDD estimates, selective migration can only drive our results if it occurs around the line of contact. Unfortunately, data on migration is only available at the county-level. As Appendix Table B5 shows, the share of people residing in the

\footnotetext{
${ }^{32}$ There is no reason to expect the number of resettled Germans arriving from several countries in Eastern Europe after the end of the war to jump discontinuously at the line of contact, since the expulsion of Germans was triggered by the agreement on post-war Europe reached at the Potsdam conference in August 1945, after the Allied withdrawal.

${ }^{33}$ Beevor (2002) writes that "at the end of January [1945], between 40,000 and 50,000 refugees were arriving in Berlin each day, mainly by train" (p.48).

${ }^{34}$ According to records of the West German Federal Ministry of Displaced Persons, Refugees and War Victims, more than 2.7 million relocated from East to West Germany-corresponding to $15 \%$ of the 1949 population - between 1949 and 1961, when the Berlin wall was built (Rühle and Holzweißig, 1988).

${ }^{35}$ Appendix Table B4 shows the decomposition of the population in each state in 1946 by place of residence at the start of the war in 1939. The shares above are fairly comparable across states, except for Mecklenburg-Vorpommern, a largely rural state that experienced a large land reform in 1945 and, as a result, attracted a larger share of migrants (Naimark, 1997).
} 
same state as in 1939 does not vary discontinuously around the line of contact. We can also corroborate the lack of evidence for selective migration using municipality-level information on the population composition in 1946 (Table 6). In Panel A, each column shows RDD estimates using a different variable in the census as dependent variable. All columns use the same fully specified regression discontinuity model (i.e. Table 3, column 5). Column 1 shows that the total population, while larger on the Allied side of the line, does not jump discontinuously at the line of contact. Furthermore, the estimate is very similar to the baseline estimate for 1933 population in Table 1, providing strong evidence of no excess migration to the Allied side of the line of contact. Column 2 shows that the female share of the population is exactly identical at the discontinuity. This further suggests that the impact of the war was homogeneous on both sides of the line (i.e. military casualties and prisoners of war). Column 3 shows no evidence of a discontinuity in the share of protestants. This is important, as the eastern provinces of Silesia and Pomerania from where many refugees originated had relatively high shares of Catholics. Columns 4-6 study the sectoral composition of the economy. We do observe ex-post differences in the industry structure: municipalities on the Allied side exhibit lower agricultural employment (column 4), matched by a larger share of workers in services and trade (column 6).

In Panel B we examine the explanatory power of the population characteristics from the 1946 census for our outcomes of interest using mediation analysis. To facilitate interpretation, odd-numbered columns replicate the previous results for protests in the 1953 uprising (column 1), SED vote share in 1946 elections (column 3), and turnout in 1946 (column 5). The even-numbered columns include all of the 1946 census variables as additional controls, on top of the RD forcing variable, border segment fixed effects and the baseline controls. We find that the estimates for incidence of protests in 1953 (column 2) and SED vote share in 1946 (column 4) barely change after we introduce the additional controls. Indeed, when using a bounding exercise (Oster, 2019), we find that the amount of selection on unobservables would need to be exceptionally large - 1.5 times higher than the amount of selection on these observable population measures - to fully explain away our findings. ${ }^{36}$ While differential migration across the line may have certainly occurred, differences in population size and in the characteristics of the local population cannot explain away our core findings on measures of political resistance.

[Table 6 here]

\footnotetext{
${ }^{36}$ This exercise is implemented using psacalc and the most conservative parametrization of $\bar{R}^{2}=1$.
} 


\subsection{Persistent differences in policies}

Differences in governance quality. Another explanation for the stronger opposition to dictatorship in the area initially occupied by the Allies is that, despite the short duration of this occupation, it allowed for the implementation of policies causing long-lasting benefits to the local population. ${ }^{37}$ While this is certainly a theoretical possibility, the historical reading suggests that it is unlikely to be the case. Following the German capitulation, the occupying forces had to attend to a host of pressing issues and the welfare of the local population was not a top priority for either occupation force (Ziemke, 1976; Stivers and Carter, 2017). ${ }^{38}$ Most of the domestic policies concerned the restoration of basic governance and the immediate survival of German civilians (food, shelter, heating), thus only affecting the short-run well-being of the population. Uncertainty about the duration of Allied presence within the Soviet occupation zone further hindered any planning for long-run policies in the area (Ziemke, 1976; Henke, 2009).

Even if no policies with long-lasting effects were implemented during the fleeting Allied occupation, a potential source of persistence could be the appointment of mayors. In this regard, the military administration on both sides quickly appointed municipal mayors in occupied areas, as part of the movement for a swift return to local selfgovernance. While the SMAD made appointments mostly based on partisan criteria (Naimark, 1997), the Allied administration may have used selection criteria conducive to higher-quality appointments. To investigate this possibility, we hand-collected data on the mayors of 173 cities and towns between 1925-1955. To do so, we conducted careful desk research, consulting the contemporary websites and the historical registers of the towns. Whenever data was unavailable from public sources, we contacted the local archive or press office of the city to collect the information. For each mayor, we gathered information on the term dates, as well as the authority that made the appointment. Overall, we were able to cover $79 \%$ of all towns and cities with more than 10,000 inhabitants. ${ }^{39}$

Despite the small sample size, our data shows stark differences in the partisan affiliation of initial mayoral appointments across the line of contact. On the Soviet side,

\footnotetext{
${ }^{37}$ Ferwerda and Miller (2014), exploiting an arbitrary division of French municipalities into German vs. Vichy-governed areas show that political devolution reduces resistance to foreign rule.

${ }^{38}$ First, troops had to be relocated, with some returning to their country of origin, others being redeployed to other theaters of war and others being reassigned to administrative duties in the occupation zones. Second, hundreds of thousands of displaced persons had to find a way back to their home. Third, an also very large number of prisoners of war had to be dealt with, in tandem with the search for Nazi criminals still on the loose.

${ }^{39}$ We find no evidence of selective non-response between Allied- and Soviet-occupied areas.
} 
$53 \%$ of appointed mayors were members of the KPD and a further $28 \%$ belonged to the SPD. Only $8 \%$ of Soviet-appointed mayors had no party affiliation. On the Allied side, only $12 \%$ of mayors came from the KPD and $32 \%$ came from the SPD. A further $32 \%$ had no party affiliation. The Allies mostly appointed previous office-holders from the Weimar Republic, who were politically persecuted during the Nazi regime, preferably with liberal views (Schneider, 1989; Welsh, 2010). The key question, however, is whether Allied-appointed mayors remained in office after the Soviet take-over.

Figure 6 shows separately for the Allied and Soviet areas the distribution of mayoral appointments in each month of $1945 .^{40}$ In the panel for the Allied area, we distinguish between mayors appointed during the brief Allied presence and those that were appointed during the stable Soviet occupation. In this panel, we observe two waves of appointments: the first one corresponds to mayors appointed by the Allies, peaking in April, and the second wave reflects a series of replacements made by the Soviet administration once it was fully in control. In contrast, Soviet-occupied areas only see a single major wave of appointments, peaking in May. Hence, we do not observe any meaningful persistence in appointments at the apex of the local administration. In fact, less than one in five Allied-occupied towns in our data still had a mayor installed by the Allied forces one year after the end of the war. Importantly, the new mayors appointed by the Soviets in the Allied area look very similar in their party affiliation to the initial appointments on the Soviet side of the line of contact: $67 \%$ of the replacement mayors were from the KPD, and a further $20 \%$ from the SPD.

\section{[Figure 6 here]}

Differences in resistance and access to free media. Even if Allied-appointed mayors were quickly replaced after the Soviet take-over, Allied occupation may have fostered subsequent resistance to the dictatorship if it allowed for the development of a robust network of pro-democracy groups and, potentially, of clandestine resistance cells. These groups could have facilitated coordination and enabled civil society to overcome free-riding problems in protest participation (Olson, 1965; Tullock, 1971; Tarrow, 1998).

While also theoretically plausible, this mechanism does not find much support in the historical record. First, the short duration of the Allied occupation combined with the uncertainty about the date of withdrawal arguably hindered the Allies' ability to develop strong resistance groups. The Allied leadership focused on reestablishing law and order and keeping the German civilians alive and only slowly awakened to the new geopolitical

\footnotetext{
${ }^{40}$ Due to data limitations, we do not have sufficient observations around the cut-off to conduct a regression discontinuity design. We thus compare across the entire Allied- vs. Soviet-occupied areas.
} 
reality (Ziemke, 1976; Ambrose, 2000). Second, both the inner German border and the border between East and West Berlin remained open and fairly unregulated until 1952, suggesting that the geography of American intervention in East German politics was unlikely to be determined by the fleeting line of contact in 1945 (Murphy et al., 1997). Third, while there certainly were open and clandestine attempts at organized resistance to the budding dictatorship in East Germany, the Soviet interior ministry (NKVD) was highly effective at identifying and targeting budding attempts at organized opposition (Bruce, 2003; Gregory, 2009). The 1953 uprising posed such a large threat to the regime precisely because of its spontaneous and uncoordinated nature. Lastly, there is no evidence of Allied backing or intervention in the 1953 uprising. In the words of Grieder (2012), "Western agents... were not responsible for causing the unrest in the first place... the East German rebels of 1953 neither requested nor expected military assistance from Washington" (p.42). ${ }^{41}$

A related topic that has attracted substantial attention by academics is exposure to free media originating outside of East Germany, including West Berlin (Kern and Hainmueller, 2009; Bursztyn and Cantoni, 2016; Crabtree et al., 2018). To investigate this possibility, we use the measures of exposure to the Radio in the American Sector - RIAS developed by Crabtree et al. (2018). The results in Appendix Table B3 show, as expected, that RIAS signal strength decreases with distance to Berlin, but does not vary discontinuously at the line of contact. More importantly, the results on protests are unchanged if we control for the RIAS signal strength..

Differences in Soviet policies and misbehavior. We also consider the possibility that Soviet policies differ across the line of contact, potentially explaining stronger political opposition on the side initially occupied by the Allies. One prominent policy involved the dismantling of machinery, factories and infrastructure to be shipped back to the Soviet Union as war reparations (Ochsner, 2017). Another prominent policy was a land reform implemented in late 1945, which confiscated large estates without compensation. ${ }^{42}$ These policies could explain our findings if they disproportionately affected the Allied-occupied sector. Arguably, the discontinuous jump in the agricultural share of workers reported in Panel A of Table 6 could be the result of the differential impact of these policies. However, the results in Panel B showing that our findings are robust to

\footnotetext{
${ }^{41}$ In the 1946 elections, Allied authorities in West Berlin purposefully tried to remain neutral, partly because polls showed that the SED lacked strong popular support (Stivers and Carter, 2017).

${ }^{42}$ Naimark (1997) estimates that $25 \%$ of industrial facilities identified as targets by the Soviets were dismantled in a first wave during the summer and fall of 1945. The land reform aimed at weakening the Junker elite thought to be complicit with the Nazi regime, but faced criticism from the liberal parties out of concerns for due process and the protection of property rights (Bruce, 2003).
} 
the inclusion of these characteristics as additional controls indicates that this is not the main mechanism behind our results. More generally, the dismantling of industrial facilities and the land reform took place throughout East Germany. The historical record at no point mentions the line of contact or the Allied-occupied sector when discussing the motivations or the implementation of any Soviet policy during the occupation years.

Perhaps more likely than a differential policy impact is the possibility that individual actions and, in particular, misbehavior by the Soviet occupying forces differed after the Soviet take-over. It is well documented that the Red Army engaged in multiple excesses against the civilian population, most notably the rape of women (Naimark, 1997; Beevor, 2002; Gebhardt, 2017). ${ }^{43}$ As with other potential explanations, the question is whether Soviet misbehavior changed discontinuously after the Allied withdrawal from the Soviet zone. In this regard, the historical record is emphatic in that "even in those areas initially occupied by the American and British troops... rape became a severe problem for the German population." (Naimark, 1997, p.84) and that "incidents of rape continued to plague the lives of German women in the Soviet zone at least until the beginning of 1947" (Naimark, 1997, p.87). ${ }^{44}$ Excesses against civilians remained substantial and extended beyond rape after the Soviet take-over. For example, the police chief in Merseburg, a city on the Allied side of the line of contact reported that "from January 1, 1946 to May 3, 1946, serious crimes carried out by 'persons in Soviet Uniform'... included: 34 murders, 345 robberies after breaking and entering, 328 robberies on the street, 60 train robberies, 123 stolen cows, 212 assaults and injuries (10 ending in death), and 162 rapes" (Naimark, 1997, p.92). Hence, it seems unlikely that differential exposure to violence can explain our findings. Lack of data prevents us from probing this hypothesis further.

\subsection{Information and salience - the "glimpse of freedom"}

One remaining mechanism allowing us to explain the discontinuous jump in opposition to the GDR dictatorship at the line of contact is that short-term exposure to the Allied forces increased the perceived benefits of supporting the Allies, thus providing a clearer alternative to the status-quo of Soviet control. In contrast to the Soviet-captured side of the line, people on the Allied side were in fact exposed to the Allied regime. This exposure - while brief and not accompanied by persistent differences in policies - reduced

\footnotetext{
${ }^{43}$ The German army also engaged in rape and other forms of sexual violence among the many atrocities it perpetrated during its occupation of the Soviet Union (Wood, 2006; Henry, 2011).

${ }^{44}$ Naimark (1997) claims that the SED found little support among women in the 1946 elections due to the issue of rape. If sexual violence was lower after the Soviet take-over of the Allied-occupied area, this would arguably attenuate the magnitude of our estimates.
} 
the uncertainty and allowed people to learn about the higher quality of the Allied regime relative to the despotic and unaccountable nature of Soviet rule. In terms of our model, this corresponds to a case in which $E\left[\theta_{a} \mid \mathbf{x}\right]<\theta_{s}<\theta_{a}$.

The historical record indicates that people living in areas initially occupied by the Allies were seemingly relieved, but - importantly - they remained unsure of what Allied occupation would entail: "The Americans are coming! Excitement but no panic; excitement fluctuating between fear and joy, but tending more to joy." (Gebhardt, 2017, p.32). However, the local population quickly noticed that the Allied occupying forces were much better prepared than their Soviet counterpart: "Unlike the local branches of the American military government, the [Soviet] kommandanturas often had no specially trained staff and Soviet officers were assigned to regions and jobs about which they had little or no knowledge. There was no evidence of handbooks, and Russian maps tended to be cutouts of outdated German originals" (Naimark, 1997, p.13). Civilians also noticed that the Allied and Soviet occupying forces had different objective functions: "The Western Allies... understood the goal to be that of leaving Germany sufficient resources to maintain a standard of living equal to the average of other European countries. The Soviets... were more concerned with removing what resources remained as quickly as possible" (Stivers and Carter, 2017, p.66).

It thus seems plausible that the Allied occupation provided a benchmark against which civilians evaluated the Soviet regime. The historical record shows that the change in the identity of the occupying force was met with great apprehension: "Soon the Russians will be coming. They are preceded by rumours of atrocities, filling the population with new dread" (Gebhardt, 2017, p.32). Furthermore, even if Soviet misbehavior was homogeneous on the two sides of the line of contact, exposure to Allied rule made the drop in the rule of law highly salient to the local population: "After the arrival of the Russians... 'Rapes, assaults, murders, one after the other'" (Naimark, 1997, p.85). ${ }^{45}$

As a result, people in the Allied-occupied area were more willing to engage in costly political resistance to the budding dictatorship in the GDR when a window of opportunity arose. In the absence of this exposure, however, people only had a noisy signal about the Allied regime and lacked a clear sense of the alternative to the Soviet-propped regime. As Grieder (2012) writes, in 1953 "there was no consensus about what should replace the SED dictatorship. Although the overwhelming majority of East Germans bitterly resented Ulbricht's policies, this did not automatically make them advocates of Capitalist democracy" (p. 41). In particular, as Hirschman (1993) notes, young people

\footnotetext{
${ }^{45}$ Ironically, SMAD propaganda would later revert to portraying living conditions in the Soviet zone as superior to those in the other zones in an attempt to gain public support (Naimark, 1997).
} 
born after 1930 had only lived under dictatorship, Nazi first and Bolshevik later. In the words of author Christa Wolf (aged 24 in 1953), "we were in danger of exchanging one salvation doctrine for another; for it is much more difficult to develop new forms of feeling and thinking" (Hirschman, 1993, p.182). In this regard, it is quite telling that the majority of people arrested during the 1953 uprising were over 24 years of age. ${ }^{46}$ Unfortunately, lack of disaggregate data prevents us from exploring this point further.

\section{Conclusion}

George Orwell, in his famous novel 1984, concluded that "so long as [the masses] are not permitted to have standards of comparison, they never even become aware that they are oppressed." 47 Indeed, in many non-democracies, the lack of an alternative makes the comparison all too hard. One-party states and absolute monarchies leave no formal alternative. Hybrid regimes often suppress the opposition. The lack of welldefined political options can substantially shift the cost-benefit calculus of citizens when deciding to support or resist a regime.

This paper goes to the heart of the Cold War to study political opposition to the budding dictatorship propped by the Soviet Union in East Germany after WWII. By leveraging the idiosyncratic line of contact that partitioned the German Democratic Republic into Allied-exposed and non-exposed areas, we show that a "glimpse of freedom" of 70 days can substantially alter the propensity of citizens to engage in costly resistance against an authoritarian regime. We find that exposure to the Allies increased the likelihood of protests during the 1953 uprising that almost toppled the regime, and decreased support for the Soviet-backed party in the country's last free election in 1946.

While shedding light on a unique episode in history, data limitations prevent us from identifying the exact micro-level mechanism through which the exposure to the Allied forces translates into political behavior. We consider several alternatives, including the possibility that the Allies implemented policies with persistent effects or that people with stronger anti-Soviet views selectively migrated to the Allied-occupied area. Ultimately, a combination of historical and quantitative evidence leads us to conclude that the most plausible explanation is that the Allied occupation allowed the local population to become more aware about the difference in quality of the two occupying forces. This allowed for a clearer sense of what was at stake in the institutional dilemma that would

\footnotetext{
${ }^{46}$ Out of 2,645 arrests, $62 \%$ corresponded to ages 25 and over, $28 \%$ to ages $18-24$ and only $10 \%$ to ages 18 and under (Bruce, 2003, p.198).

${ }^{47}$ George Orwell, 1984, Chapter IX, p. 237. Penguin Modern Classics.
} 
engulf East Germany over the following years. However, we cannot distinguish, for instance, between a pure learning mechanism and the existence of reference dependence in political preferences (Alesina and Passarelli, 2019). Future work could investigate such mechanisms, for example, by collecting survey data in a contemporary setting, or running more controlled experiments in the lab or in the field.

An intriguing aspect of our findings is that the line of contact predates the formation of the new state - the German Democratic Republic - in which we study political behavior. As such, our work provides a prologue to the newly emerging and exciting literature interested in the determinants of political behavior in the German Democratic Republic (Mohr, 2019; Lichter et al., 2019; Stegmann, 2019). The fact that initial conditions matter also has broader implications for modern state building, particularly for newly-created and fragile regimes in post-conflict settings.

\section{References}

Acemoglu, D. and Robinson, J. (2005). Economic Origins of Dictatorship and Democracy. Cambridge University Press.

Alesina, A. and Fuchs-Schündeln, N. (2007). Goodbye Lenin (or Not?): The Effect of Communism on People's Preferences. American Economic Review, 97(4):1507-1528.

Alesina, A., Giuliano, P., and Reich, B. (2019). Nation-Building and Education. Working Paper.

Alesina, A. and Passarelli, F. (2019). Loss Aversion in Politics. American Journal of Political Science, 63(4):936-947.

Ambrose, S. (2000). Eisenhower and Berlin, 1945: The Decision to Halt at the Elbe. Norton, New York, NY.

Ashworth, S. (2012). Electoral Accountability: Recent Theoretical and Empirical Work. Annual Review of Political Science, 15(1):183-201.

Badsey, S., editor (2000). The Hutchinson Atlas of World War II Battle Plans: Before and After. Helicon Publishing, Oxford, UK.

Barreca, A. I., Lindo, J. M., and Waddell, G. R. (2016). Heaping-induced bias in regression-discontinuity designs. Economic Inquiry, 54(1):268-293.

Bautista, M. A., González, F., Martínez, L. R., Muñoz, P., and Prem, M. (2019). The Geography of Dictatorship and Support for Democracy. BFI Working Paper 2019-105.

Bazzi, S., Gaduh, A., Rothenberg, A. D., and Wong, M. (2019). Unity in Diversity? How Intergroup Contact Can Foster Nation Building. American Economic Review, 109(11):3978-4025. 
Becker, S., Mergele, L., and Woessmann, L. (2020). The Separation and Reunification of Germany: Rethinking a Natural Experiment Interpretation of the Enduring Effects of Communism. IZA Discussion Papers No. 13032.

Beevor, A. (2002). The Fall of Berlin, 1945. Viking Penguin, London, UK.

Berman, E. and Matanock, A. M. (2015). The Empiricists' Insurgency. Annual Review of Political Science, 18(1):443-464.

Berman, E., Shapiro, J. N., and Felter, J. H. (2011). Can Hearts and Minds Be Bought? The Economics of Counterinsurgency in Iraq. Journal of Political Economy, 119(4):766-819.

Braun, G. (1993). SBZ-Handbuch: Staatliche Verwaltungen, Parteien, gesellschaftliche Organisationen und ihre Führungskräfte in der Sowjetischen Besatzungszone Deutschlands 1945-1949. De Gruyter Oldenbourg.

Broockman, D. and Kalla, J. (2016). Durably Reducing Transphobia: A Field Experiment on Door-to-Door Canvassing. Science, 352(6282):220-224.

Bruce, G. (2003). Resistance with the People: Repression and Resistance in Eastern Germany,1945-1955. Rowman and Littlefield.

Buckow, A. (2003). Zwischen Propaganda und Realpolitik: die USA und der sowjetisch besetzte Teil Deutschlands 1945-1955, volume 13. Franz Steiner Verlag.

Bursztyn, L. and Cantoni, D. (2016). A Tear in the Iron Curtain: The Impact of Western Television on Consumption Behavior. Review of Economics and Statistics, 98(1):25-41.

Bursztyn, L., Cantoni, D., Yang, D., Yuchtman, N., and Zhang, J. (2019). Persistent Political Engagement: Social Interactions and the Dynamics of Protest Movements. mimeo.

Calonico, S., Cattaneo, M. D., and Titiunik, R. (2014). Robust Nonparametric Confidence Intervals for Regression-Discontinuity Designs. Econometrica, 82(6):2295-2326.

Cantoni, D., Yang, D. Y., Yuchtman, N., and Zhang, Y. J. (2019). Protests as Strategic Games: Experimental Evidence from Hong Kong's Antiauthoritarian Movement. Quarterly Journal of Economics, 134(2):1021-1077.

Cattaneo, M. D., Jansson, M., and Ma, X. (2018). Manipulation testing based on density discontinuity. The Stata Journal, 18(1):234-261.

Cattaneo, M. D., Jansson, M., and Ma, X. (2019). Simple Local Polynomial Density Estimators. Journal of the American Statistical Association, pages 1-7.

Conley, T. G. (1999). GMM Estimation with Cross-sectional Dependence. Journal of Econometrics, 92(1):1-45. 
Crabtree, C., Kern, H. L., and Pfaff, S. (2018). Mass Media and the Diffusion of Collective Action in Authoritarian Regimes: The June 1953 East German Uprising. International Studies Quarterly, 62(2):301-314.

Croke, K., Grossman, G., Larreguy, H., and Marshall, J. (2016). Deliberate Disengagement: How Education Can Decrease Political Participation in Electoral Authoritarian Regimes. American Political Science Review, 110(3):579-600.

Dell, M. (2010). The persistent effects of Peru's mining mita. Econometrica, 78(6):18631903.

Dell, M. and Querubin, P. (2018). Nation Building Through Foreign Intervention: Evidence from Discontinuities in Military Strategies. Quarterly Journal of Economics, 133(2):701-764.

Eder, C. and Halla, M. (2018). On the Origin and Composition of the German East-West Population Gap. mimeo.

Enikolopov, R., Makarin, A., and Petrova, M. (2019). Social Media and Protest Participation: Evidence from Russia. Econometrica (Forthcoming).

Falter, J. W. (1997). Die Landtagswahlen von 1946 in der Sowjetischen Besatzungszone. GESIS Datenarchiv, Köln. ZA2879 Datenfile Version 1.0.

Falter, J. W. and Hänisch, D. (1990). Wahl-und sozialdaten der kreise und gemeinden des deutschen reiches von 1920 bis 1933. GESIS Datenarchiv, Köln. ZA8013 Datenfile Version 1.0, 1.

Falter, J. W. and Weins, C. (2013). Die Wahlen in der Sowjetisch Besetzten Zone von 1946. Eine wahlhistorische Analyse. Historical Social Research/Historische Sozialforschung. Supplement, pages 333-354.

Ferwerda, J. and Miller, N. (2014). Political Devolution and Resistance to Foreign Rule: A Natural Experiment. American Political Science Review, 108(3):642-660.

Freedom House (2020). Freedom in the World 2020. A Leaderless Struggle for Democracy.

Fuchs-Schündeln, N. and Masella, P. (2016). Long-Lasting Effects of Socialist Education. The Review of Economics and Statistics, 98(3):428-441.

Gagliarducci, S., Onorato, M., Sobbrio, F., and Tabellini, G. (2020). War of the Waves: Radio and Resistance during World War II. American Economic Journal: Applied Economics.

Gebhardt, M. (2017). Crimes Unspoken: The Rape of German Women at the End of the Second World War. Polity, Cambridge,UK. 
Gilbert, M. (2008). The Routledge Atlas of the Second World War. Routledge, New York, NY.

Gregory, P. R. (2009). Terror by Quota: State Security from Lenin to Stalin (an Archival Study). Yale University Press.

Grieder, P. (2012). The German Democratic Republic. Palgrave Macmillan, West Sussex, UK.

Gurr, T. R. (1970). Why Men Rebel. Princeton University Press.

Hänisch, D. (1989). Inhalt und Struktur der Datenbank Wahl- und Sozialdaten der Kreise und Gemeinden des Deutschen Reiches von 1920 bis 1933 . Historical Social Research.

Henke, K.-D. (2009). Die amerikanische Besetzung Deutschlands. Walter de Gruyter.

Henry, N. (2011). War and Rape: Law, Memory and Justice. Routledge, New York, NY.

Hirschman, A. O. (1993). Exit, Voice, and the Fate of the German Democratic Republic: An Essay in Conceptual History. World Politics, 45(2):173-202.

Imbens, G. W. and Lemieux, T. (2008). Regression Discontinuity Designs: A Guide to Practice. Journal of Econometrics, 142(2):615-635.

Jones, M. (2015). After Hitler: The Last Ten Days of World War II in Europe. New American Library, New York, NY.

Kern, H. L. and Hainmueller, J. (2009). Opium for the Masses: How Foreign Media Can Stabilize Authoritarian Regimes. Political Analysis, 17(4):377-399.

Kocher, M. A., Pepinsky, T. B., and Kalyvas, S. N. (2011). Aerial Bombing and Counterinsurgency in the Vietnam War. American Journal of Political Science, 55(2):201218.

Kopstein, J. (1996). Chipping away at the state: workers' resistance and the demise of East Germany. World Politics, 48(3):391-423.

Kowalczuk, I.-S. (2003). 17 Juni 1953-Volksaufstand in der DDR Ursachen, Abläufe, Folgen. Edition Temmen.

Laudenbach, C., Malmendier, U., and Niessen-Ruenzi, A. (2019). The Long-lasting Effects of Experiencing Communism on Attitudes towards Financial Markets. mimeo.

Ledyard, J. O. (1984). The Pure Theory of Large Two-Candidate Elections. Public Choice, 44(1):7-41.

Lichter, A., Loeffler, M., and Siegloch, S. (2019). The Long-Term Costs of Government Surveillance: Insights from Stasi Spying in East Germany. Journal of the European Economic Association (forthcoming). 
MacDonald, C. (1993). The Last Offensive: United States Army in World War II, The European Theater of Operations. Center of Military History, United States Army, Washington, D.C.

Mohr, C. (2019). Carrots and Sticks: Targeting the Opposition in an Autocratic Regime. mimeo.

Murphy, D., Kondrashev, S., and Bailey, G. (1997). Battleground Berlin: CIA vs KGB in the Cold War. Yale University Press.

Naimark, N. (1997). The Russians in Germany: A History of the Soviet Zone of Occupation, 1945-1949. Belknap Press.

Natkiel, R. (1985). Atlas of World War II. Bison Books, Greenwich, CT.

Ochsner, C. (2017). Dismantled Once, Diverged Forever? A Quasi-natural Experiment of the Red Army's Misdeeds in Post-WWII Europe. mimeo.

Ochsner, C. and Roesel, F. (2020). Migrating Extremists. Economic Journal (forthcoming).

Olson, M. (1965). The Logic of Collective Action: Public Goods and the Theory of Groups. Harvard University Press.

Oster, E. (2019). Unobservable Selection and Coefficient Stability: Theory and Evidence. Journal of Business 85 Economic Statistics, 37(2):187-204.

Pimlott, J. (1995). The Viking Atlas of World War II. Viking, London, UK.

Pons, V. (2018). Will a Five-Minute Discussion Change Your Mind? A Countrywide Experiment on Voter Choice in France. American Economic Review, 108(6):1322-63.

Rozenas, A. and Zhukov, Y. (2020). Mass Repression and Political Loyalty: Evidence from Stalin's Terror by Hunger. American Political Science Review (forthcoming).

Rühle, J. and Holzweißig, G. (1988). 13. August 1961. Die Mauer von Berlin. Wissenschaft und Politik.

Schneider, D. M. (1989). Renaissance und Zerstörung der kommunalen Selbstverwaltung in der sowjetischen Besatzungszone. Oldenbourg.

Shadmehr, M. and Bernhardt, D. (2011). Collective Action with Uncertain Payoffs: Coordination, Public Signals, and Punishment Dilemmas. American Political Science Review, 105(4):829-851.

Shepsle, K. A. (1972). The Strategy of Ambiguity: Uncertainty and Electoral Competition. American Political Science Review, 66(2):555-568.

Stegmann, A. (2019). When East Meets West: Interpersonal Contact and the Demand for Democracy. mimeo. 
Steiner, A. (2013). The Plans that Failed: An Economic History of the GDR. Berghahn Books.

Stivers, W. and Carter, D. (2017). The City Becomes a Symbol: The US Army in the Occupation of Berlin, 1945-1949. Center of Military History, US Army.

Svolik, M. W. (2013). Learning to Love Democracy: Electoral Accountability and the Success of Democracy. American Journal of Political Science, 57(3):685-702.

Tarrow, S. (1998). Power in Movement: Social Movements and Contentious Politics. Cambridge University Press.

Toland, J. (2003). The Last 100 Days: The Tumultuous and Controversial Story of the Final Days of World War II in Europe. Modern Library, New York, NY.

Tullock, G. (1971). The Paradox of Revolution. Public Choice, 11:89-99.

U.S. Army (1945). Atlas of the World Battle Fronts in Semimonthly Phases: A Supplement to the Biennial Report of the Chief of Staff of the United States Army to the Secretary of War (July 1, 1943 to June 30, 1945). U.S. Army.

Welsh, H. (2010). Revolutionärer Wandel auf Befehl?: Entnazifizierungs-und Personalpolitik in Thüringen und Sachsen (1945-1948), volume 58. Walter de Gruyter.

Wood, E. J. (2006). Variation in Sexual Violence during War. Politics and Society, $34(3): 307-341$.

Ziemke, E. (1976). The U.S. Army in the Occupation of Germany: 1944-1946. Center of Military History, United States Army, Washington, D.C. 


\section{Figures}

Figure 1: Occupied counties in East Germany by date of 1945

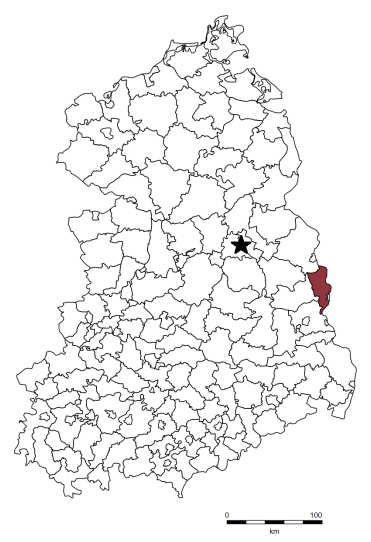

(a) January 31

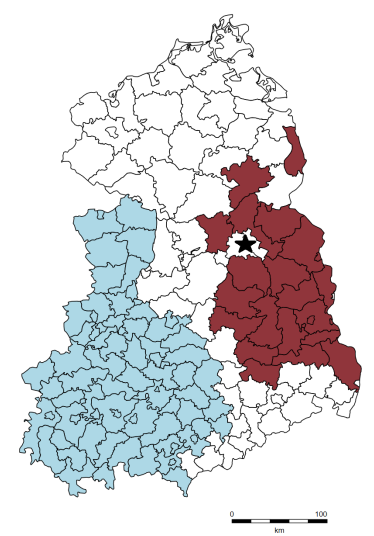

(d) April 25

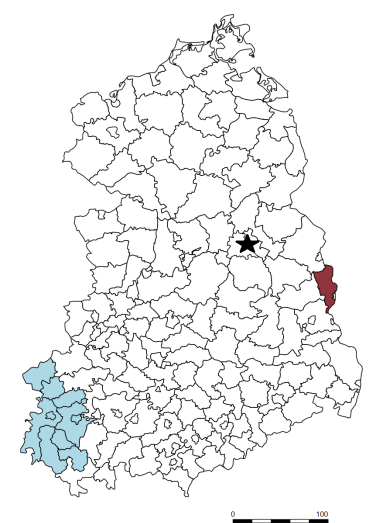

(b) April 9

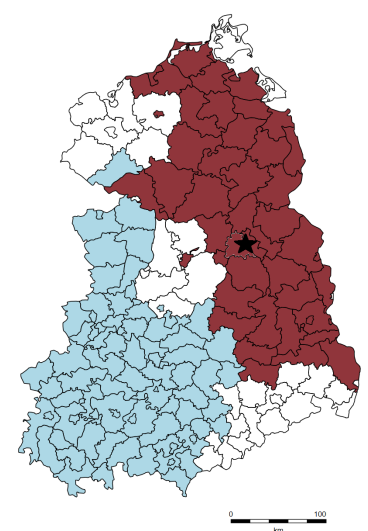

(e) May 2

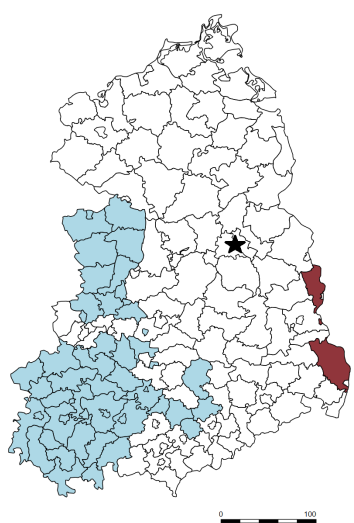

(c) April 16

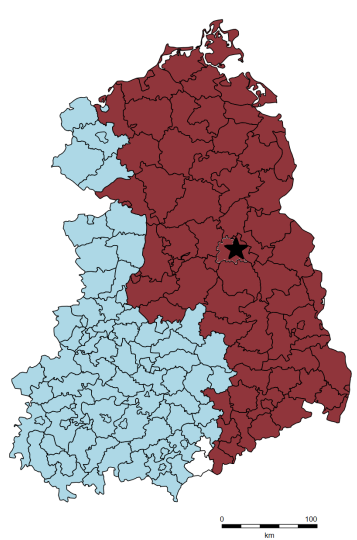

(f) May 7

Notes: Blue coloured areas occupied by the Allied and red marks coloured occupied by the Soviet. Occupation date of a county refers to the occupation of its largest city. County boundaries from January 1, 1948. The uncoloured counties in the south, an area which became later known as the Free Republic of Schwarzenberg, were initially not occupied by Allied or Soviet forces and only captured by Soviet forces on June 24, 1945. 
Figure 2: Soviet vs. Allied occupation frontier line in East Germany 1945

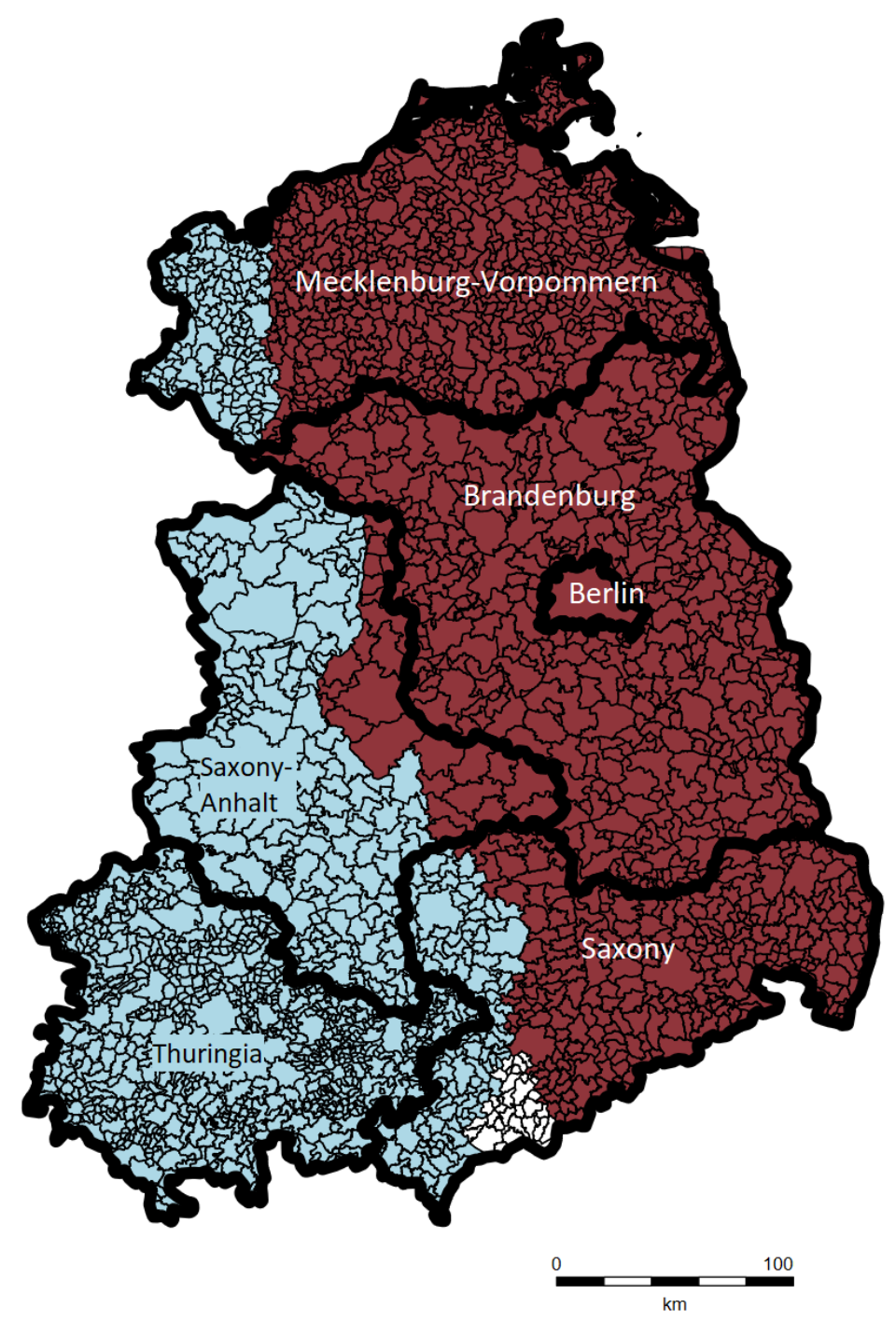

Notes: Map shows East Germany and the state and municipality boundaries of the contemporary Federal Republic of Germany (as of December 31 2016), with the occupation frontier between Soviet (Red) and Allied (British/Canadian/US) forces (Blue). The uncoloured municipalities in the south, an area which became later known as the Free Republic of Schwarzenberg, were initially not occupied by Allied or Soviet forces and only captured by Soviet forces on June 24, 1945. 
Figure 3: Days of exposure to Allied forces

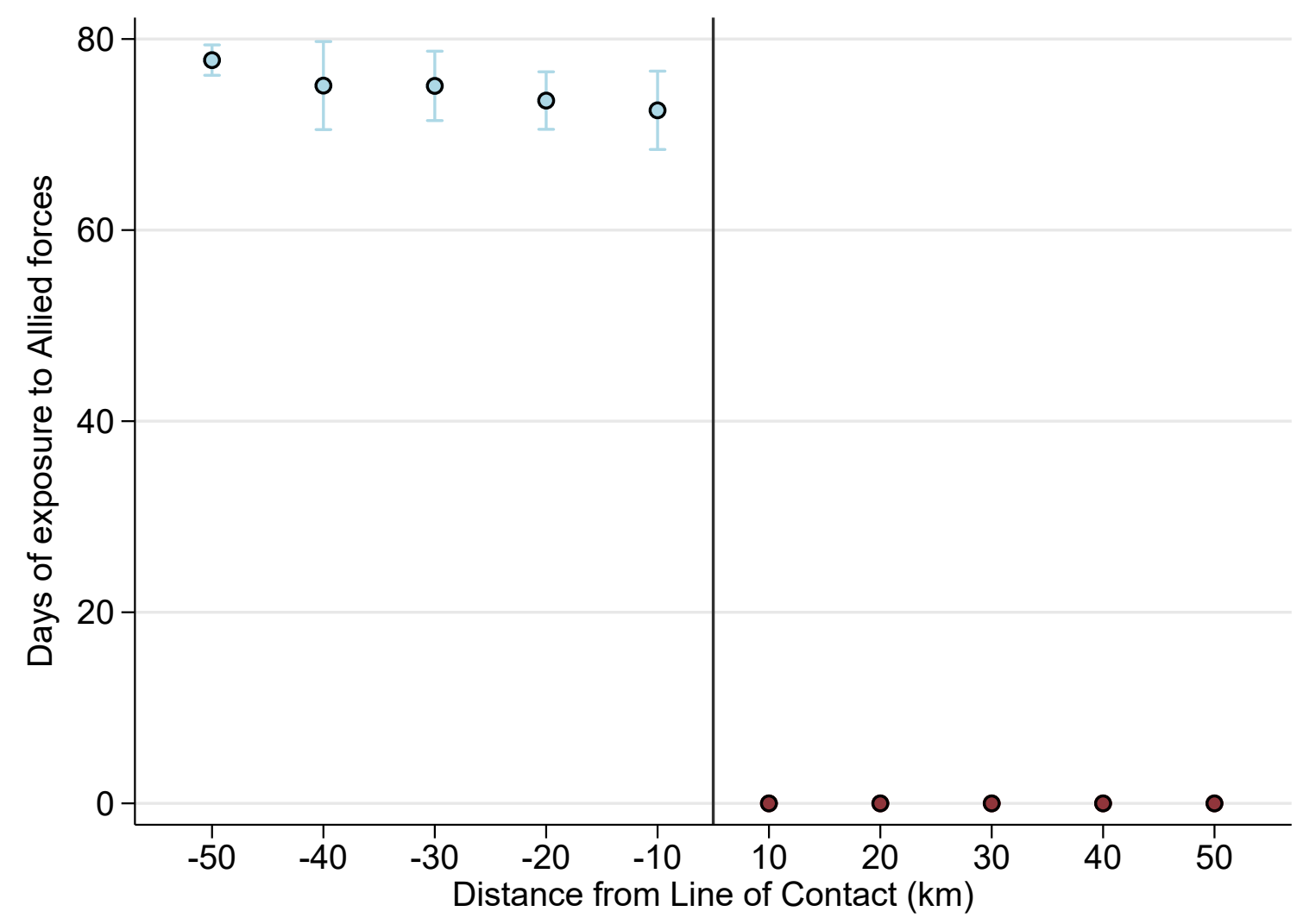

Notes: Units of observation are municipalities in East Germany as of 1946 . Dependent variable is the number of days of exposure to Allied forces. Exposure is calculated using the occupation date of the largest city in the county (Kreis) in which the municipality is located. For this calculation, we also set July 31945 as the date when Allied forces withdrew from the Soviet zone (see section 2). Raw means computed by $10 \mathrm{~km}$ bins. Negative numbers denote the Allied side of the line of contact and positive numbers the Soviet side. Standard errors clustered at the county-level. Whiskers indicate $95 \%$ confidence intervals. 
Figure 4: Protest in 1953 and exposure to Allied forces

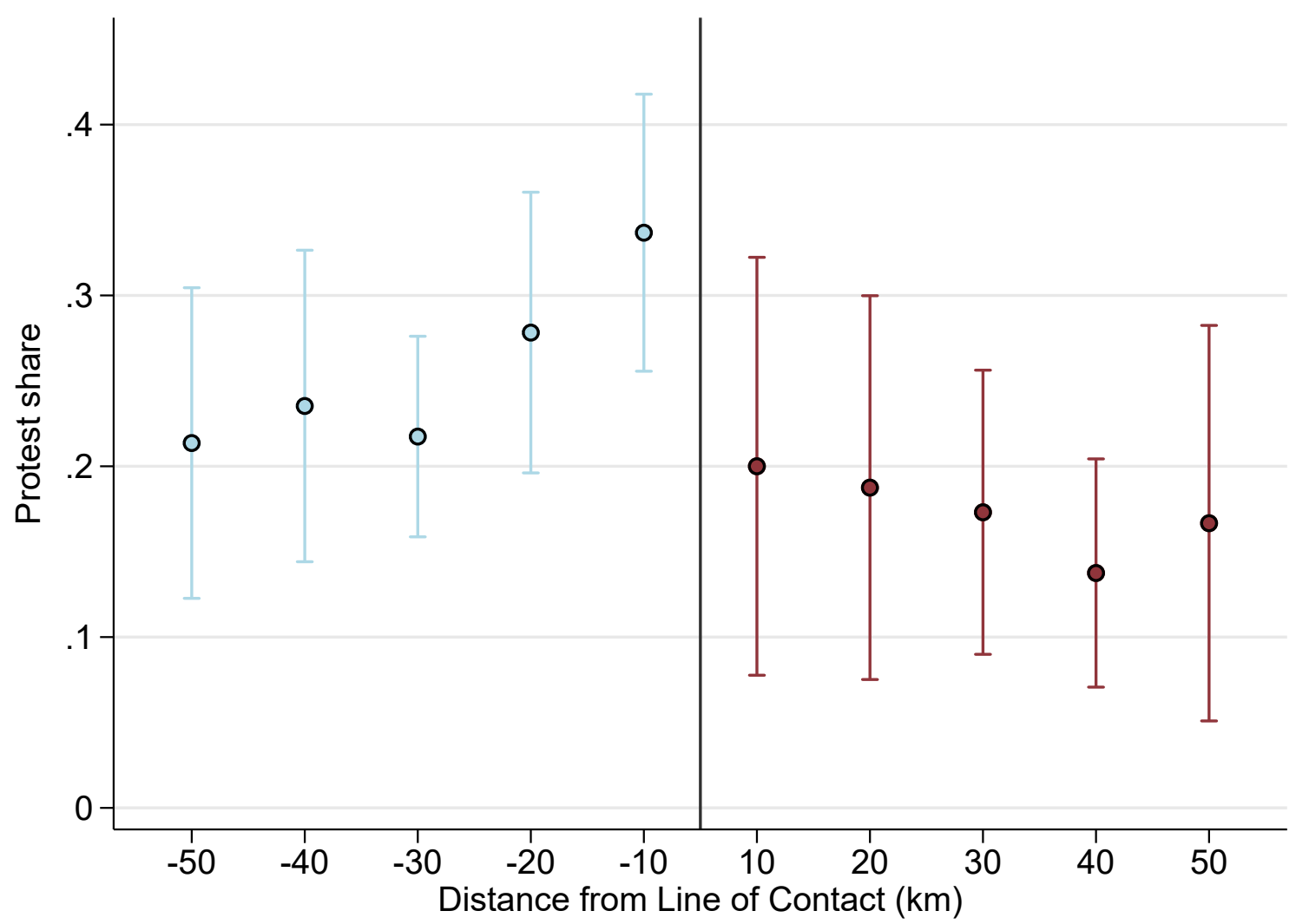

Notes: The dependent variable is an indicator for the occurrence of protests during the 1953 uprising. The sample consists of all East German municipalities with a population above 1,000. Raw means computed by $10 \mathrm{~km}$ bins. Negative numbers denote the Allied side of the line and positive numbers the Soviet-occupied side. Standard errors clustered at the county-level in parentheses. Whiskers indicate $95 \%$ confidence intervals. 
Figure 5: Vote share for communists (SED / KPD) in East vs. West Berlin

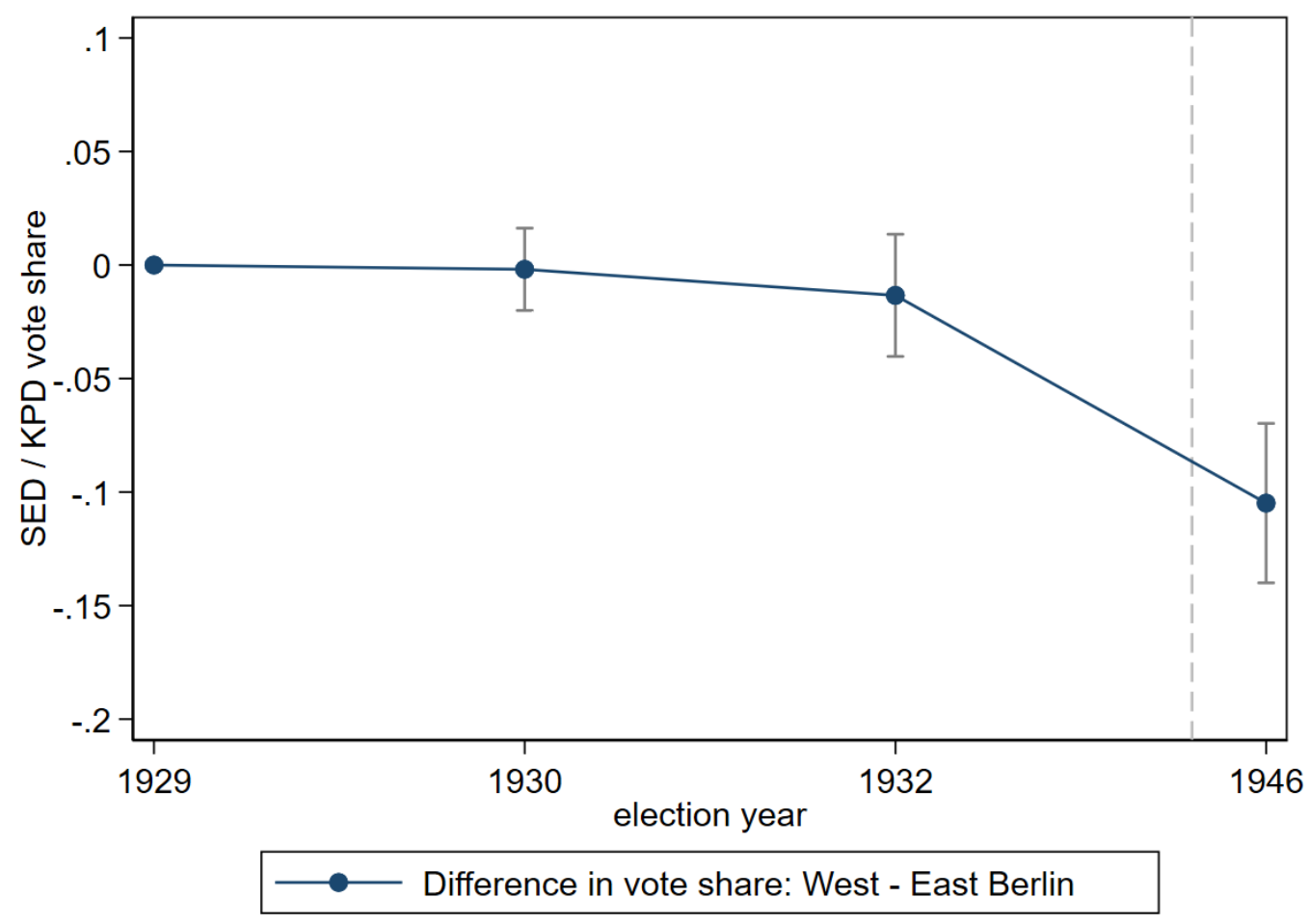

Notes: Dfferences in the vote share for the Socialist Unity Party (SED) and its predecessor, the Communist Party of Germany (KPD) between East and West Berlin, before and after the division into Soviet and Allied administered zones. After 1945 (as highlighted by the dashed line), East Berlin was under Soviet control, while West Berlin was ceded to (Western) Allied control. Units of observation are 68 districts of Berlin (33 in West Berlin). 1929 was a municipal election, 1930 and 1932 federal elections and 1946 the Berlin state election. Estimation includes district and year fixed effects (see Table 5, column 5 for the regression results). Standard errors are clustered at the district-level. Whiskers indicate $95 \%$ confidence intervals. 
Figure 6: Appointment of mayors by Allied exposed vs. non-exposed areas
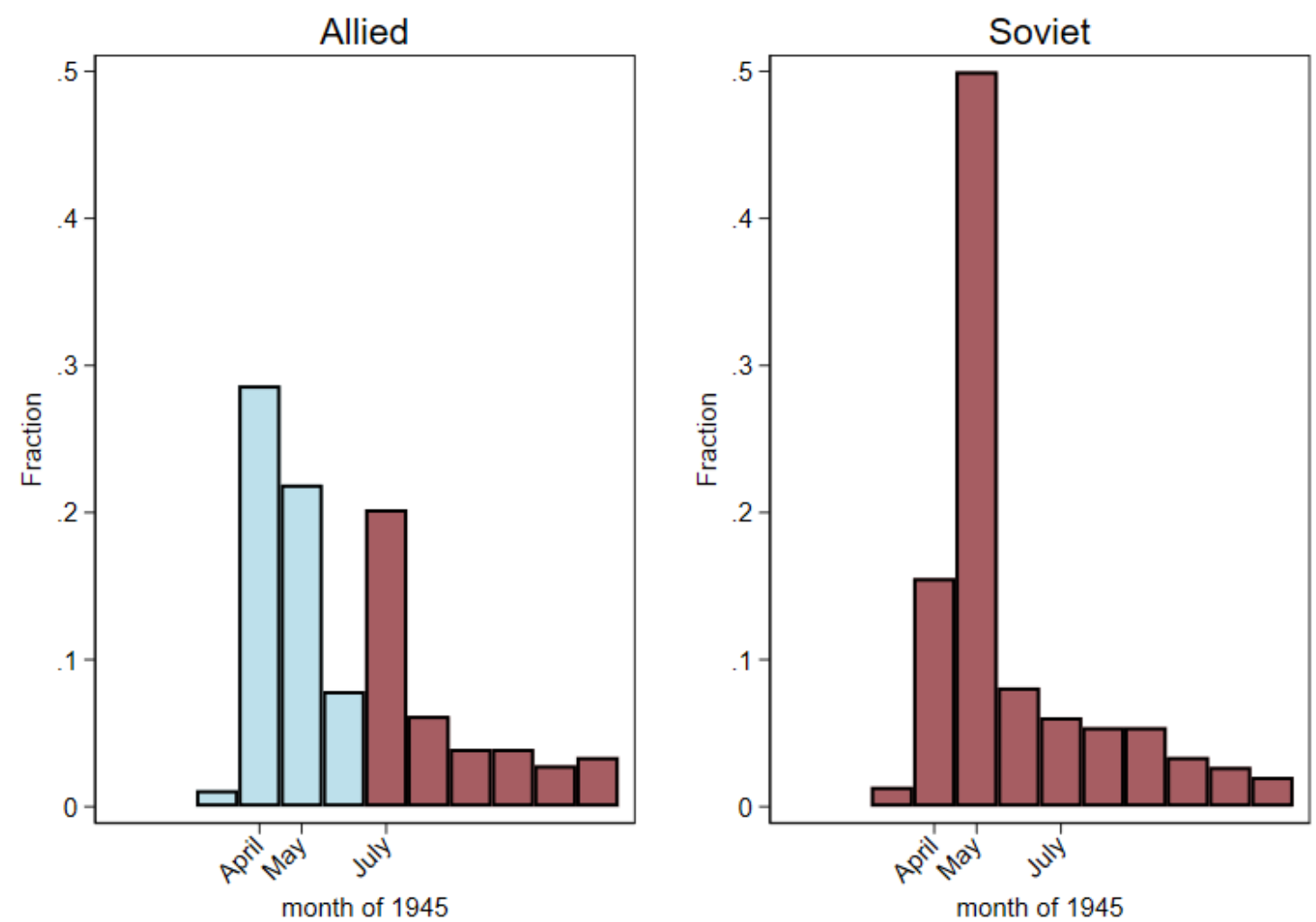

Notes: Figures show the distribution of start months for mayors in Allied and Soviet-occupied cities in 1945, $N=326$ (156 cities). Blue marks Allied appointed mayors, while red marks Soviet appointed mayors. 
Tables 
Table 1: Descriptive statistics for Allied exposed vs. non-exposed areas

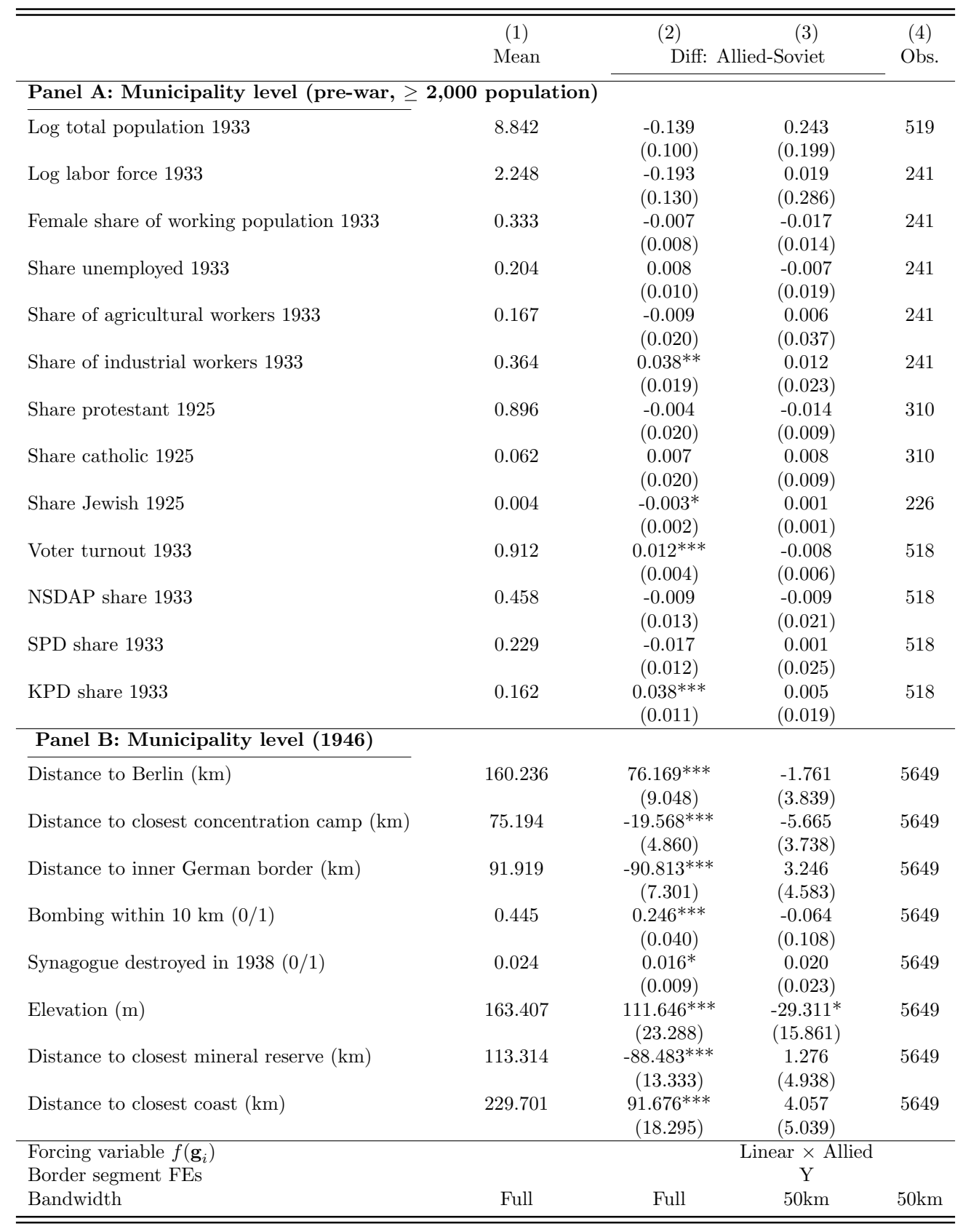

Notes: Units of observation in Panel A are municipalities in East Germany with a population size above 2,000 in the Weimar Republic. Units of observation in Panel B are municipalities in East Germany as of 1946 (corresponding to the 1946 election and census outcomes). Column 1 shows the sample mean, column 2 shows the mean difference between Allied exposed and non-exposed areas. Column 3 shows the difference after the inclusion of the forcing variable and ten border segment FEs with a sample window of $50 \mathrm{~km}$ around the line of contact. Column 4 shows the number of observations for the $50 \mathrm{~km}$ bandwidth sample. Labor force is defined as all individuals that were either self-employed, civil servants, employees, workers or domestic workers. Bombing within $10 \mathrm{~km}$ indicates that aerial bombings in WWII occurred within the proximity of the municipality. See section 3 for a more detailed description of the data sources and variables used. Standard errors clustered at the county-level in parentheses. $* * * p<0.01, * *$ $p<0.05, * p<0.1$ 
Table 2: Exposure to Allied forces around the Line of Contact

\begin{tabular}{|c|c|c|c|c|c|}
\hline \multirow[b]{3}{*}{ Mean of dep. variable } & (1) & $(2)$ & (3) & $(4)$ & $(5)$ \\
\hline & \multicolumn{5}{|c|}{ Days of Allied exposure } \\
\hline & 42.594 & 42.594 & 42.594 & 42.594 & 42.594 \\
\hline \multirow[t]{3}{*}{ Allied } & $74.724^{* * *}$ & $71.369^{* * *}$ & $71.858 * * *$ & $72.164^{* * *}$ & $73.328^{* * *}$ \\
\hline & $(1.400)$ & $(2.118)$ & $(1.905)$ & $(2.064)$ & $(1.711)$ \\
\hline & [1.394] & [2.109] & [1.896] & {$[2.052]$} & {$[1.700]$} \\
\hline \multirow{3}{*}{$\begin{array}{l}\text { Borcing varlable } J\left(\mathbf{g}_{i}\right) \\
\text { Border segment FEs } \\
\text { Full controls }\end{array}$} & & \multirow[t]{3}{*}{ Linear } & \multicolumn{3}{|c|}{ Linear $\times$ Allied } \\
\hline & & & \multirow{2}{*}{\multicolumn{2}{|c|}{$\mathrm{Y}$}} & $\bar{Y}$ \\
\hline & & & & & Y \\
\hline Bandwidth & $50 \mathrm{~km}$ & $50 \mathrm{~km}$ & $50 \mathrm{~km}$ & $50 \mathrm{~km}$ & $50 \mathrm{~km}$ \\
\hline Observations & 5,649 & 5,649 & 5,649 & 5,649 & 5,649 \\
\hline
\end{tabular}

Notes: Units of observation are East German municipalities of 1946. Dependent variable is the number of days with exposure to Allied forces. Exposure is calculated by using the occupation date of the largest city of the municipalities' counties and using July 3, 1945 as the day when Allied forces had retreated (see section 2). Border segment FEs consist of ten equally large segments cut along the latitude of municipalities. Controls are all municipality-level variables of Table 1 (Panel B), and latitude / longitude. Standard errors clustered at the county-level in parentheses. Conley standard errors in square brackets. ${ }^{* * *} p<0.01,{ }^{* *} p<0.05,{ }^{*} p<0.1$ 
Table 3: Allied exposure and 1953 protests

\begin{tabular}{|c|c|c|c|c|c|}
\hline \multirow[b]{3}{*}{ Mean of dep. variable } & (1) & $(2)$ & $(3)$ & (4) & $(5)$ \\
\hline & \multicolumn{5}{|c|}{ Dependent variable: Presence of protest } \\
\hline & 0.220 & 0.220 & 0.220 & 0.220 & 0.220 \\
\hline \multirow[t]{3}{*}{ Allied } & $0.081^{* *}$ & $0.163^{* * *}$ & $0.142^{* *}$ & $0.143^{* * *}$ & $0.170^{* * *}$ \\
\hline & $(0.033)$ & $(0.057)$ & $(0.058)$ & $(0.051)$ & $(0.061)$ \\
\hline & {$[0.026]$} & [0.059] & {$[0.058]$} & {$[0.056]$} & {$[0.061]$} \\
\hline Forcing variable $f\left(\mathbf{g}_{i}\right)$ & & Linear & \multicolumn{3}{|c|}{ Linear $\times$ Allied } \\
\hline Border segment FEs & & & \multirow{2}{*}{\multicolumn{2}{|c|}{$\mathrm{Y}$}} & $\mathrm{Y}$ \\
\hline Full controls & & & & & $\mathrm{Y}$ \\
\hline Sample & \multicolumn{5}{|c|}{ Population $\geq 1,000$} \\
\hline Bandwidth & $50 \mathrm{~km}$ & $50 \mathrm{~km}$ & $50 \mathrm{~km}$ & $50 \mathrm{~km}$ & $50 \mathrm{~km}$ \\
\hline Observations & 968 & 968 & 968 & 968 & 968 \\
\hline
\end{tabular}

Notes: The dependent variable is an indicator for the occurrence of protests during the 1953 uprising. The sample consists of all East German municipalities with a population above 1,000. Border segment FEs consist of ten equally large segments cut along the latitude of municipalities. Controls are all municipality-level variables of Table 1 (Panel B), and latitude / longitude. Standard errors clustered at the county-level in parentheses. Conley standard errors in square brackets. ${ }^{* * *}$ $p<0.01,{ }^{* *} p<0.05, * p<0.1$ 
Table 4: Allied exposure and 1946 electoral outcomes

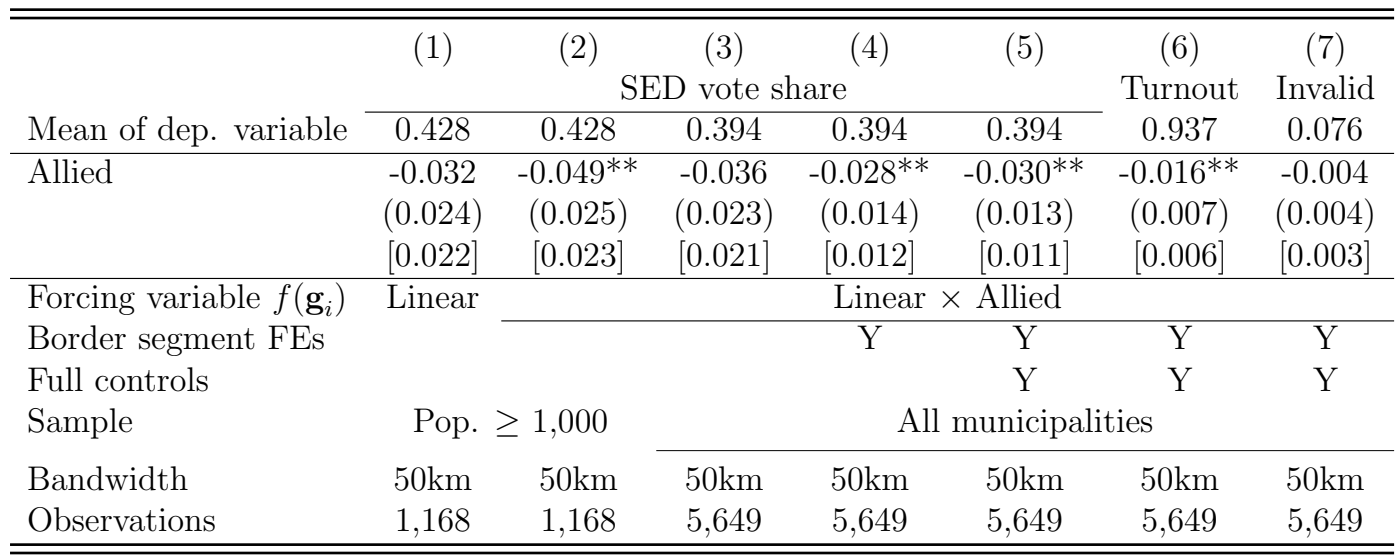

Notes: Units of observation are East German municipalities of 1946. Dependent variable is the vote share of the Socialist Unity Party of Germany (SED) in the 1946 Soviet occupation zone state elections calculated as the share of SED votes among the eligible population. Voter turnout is the share of cast votes (valid and invalid) and invalid denotes the share of invalid votes of the eligible population. Border segment FEs consist of ten equally large segment cut along the latitude of municipalities. Controls are all municipality-level variables of Table 1 (Panel B), and latitude / longitude. Regressions are weighted by the eligible voting population. Standard errors clustered at the county-level in parentheses. Conley standard errors in square brackets. ${ }^{* * *} \mathrm{p}<0.01,{ }^{* *} \mathrm{p}<0.05$, $* \mathrm{p}<0.1$ 
Table 5: SED support and Allied control: Within Berlin variation

\begin{tabular}{|c|c|c|c|c|c|c|}
\hline \multirow[t]{2}{*}{ Dependent variable: } & \multicolumn{3}{|c|}{ SED vote share } & \multicolumn{3}{|c|}{$\mathrm{SED} / \mathrm{KPD}$ vote share } \\
\hline & (1) & (2) & (3) & (4) & (5) & (6) \\
\hline Mean of dep. variable & 0.206 & 0.206 & 0.182 & 0.209 & 0.237 & 0.224 \\
\hline Allied & $\begin{array}{c}-0.176^{* * *} \\
(0.012)\end{array}$ & $\begin{array}{c}-0.136^{* * *} \\
(0.018)\end{array}$ & $\begin{array}{c}-0.134^{* * *} \\
(0.021)\end{array}$ & & & \\
\hline Allied x 1930 & & & & & $\begin{array}{l}-0.002 \\
(0.009)\end{array}$ & $\begin{array}{c}0.002 \\
(0.010)\end{array}$ \\
\hline Allied x 1932 & & & & & $\begin{array}{l}-0.013 \\
(0.013)\end{array}$ & $\begin{array}{l}-0.026 \\
(0.020)\end{array}$ \\
\hline Allied x 1946 & & & & $\begin{array}{c}-0.104^{* * *} \\
(0.019)\end{array}$ & $\begin{array}{c}-0.105^{* * *} \\
(0.018)\end{array}$ & $\begin{array}{c}-0.099 * * * \\
(0.021)\end{array}$ \\
\hline Election year FE & & & & $\mathrm{Y}$ & $\mathrm{Y}$ & $\mathrm{Y}$ \\
\hline District FE & & & & Y & Y & $\mathrm{Y}$ \\
\hline Latitude / longitude & & $\mathrm{Y}$ & Y & & & \\
\hline $\begin{array}{l}\text { Common longitude support } \\
\text { Election sample: }\end{array}$ & & & Y & & & $\mathrm{Y}$ \\
\hline 1946 Berlin state election & Y & Y & Y & Y & Y & Y \\
\hline 1929 municipal elections & & & & $\mathrm{Y}$ & Y & Y \\
\hline 1930 and 1932 federal elections & & & & & $\mathrm{Y}$ & $\mathrm{Y}$ \\
\hline Observations & 75 & 75 & 49 & 126 & 247 & 164 \\
\hline
\end{tabular}

Notes: Unit of observation is the district in Berlin. Relating vote share of the Socialist Unity Party (SED) in 1946 to the identity of the occupying forces. Allied controlled districts consist of the American, British and French sector. Columns 1-3 use only the 1946 state election. Columns 4-6 include pre-war elections in a difference-in-differences setting using the vote share of the Communist Party of Germany (KPD), the predecessor of the SED. Column 4 restricts this to the 1929 local election, the final two columns additionally include federal elections. Common longitudinal support indicates that only districts are included which are - in the case of Allied controlled districts - only as far West as the most western Soviet controlled district, and vice versa. Standard errors (robust in columns 1-3, clustered at the district level in columns 4-6) in parentheses. ${ }^{* * *} p<0.01$, ** $p<0.05,{ }^{*} p<0.1$. 
Table 6: Testing for demographic changes around the line of contact

\begin{tabular}{|c|c|c|c|c|c|c|}
\hline \multirow[t]{3}{*}{ Panel A: Census 1946} & \multirow{3}{*}{$\begin{array}{c}(1) \\
\ln \text { Total } \\
\text { Pop. }\end{array}$} & $(2)$ & $(3)$ & $(4)$ & $(5)$ & (6) \\
\hline & & \multicolumn{5}{|c|}{ Share of total population } \\
\hline & & Female & Protestant & Agr. & Ind. & Svc. \& Trade \\
\hline Mean of dep. var & 6.266 & 0.563 & 0.835 & 0.469 & 0.230 & 0.103 \\
\hline \multirow[t]{3}{*}{ Allied } & 0.222 & -0.000 & -0.012 & $-0.072^{* *}$ & 0.033 & $0.048^{* *}$ \\
\hline & $(0.146)$ & $(0.003)$ & $(0.010)$ & $(0.035)$ & $(0.023)$ & $(0.020)$ \\
\hline & {$[0.073]$} & {$[0.003]$} & {$[0.008]$} & {$[0.029]$} & {$[0.019]$} & {$[0.017]$} \\
\hline Bandwidth & $50 \mathrm{~km}$ & $50 \mathrm{~km}$ & $50 \mathrm{~km}$ & $50 \mathrm{~km}$ & $50 \mathrm{~km}$ & $50 \mathrm{~km}$ \\
\hline Forcing variable $f\left(\mathbf{g}_{i}\right)$ & \multicolumn{6}{|c|}{ Linear $\times$ Allied } \\
\hline Border segment FEs & $\mathrm{Y}$ & $\mathrm{Y}$ & $\mathrm{Y}$ & $\mathrm{Y}$ & $\mathrm{Y}$ & $\mathrm{Y}$ \\
\hline Full controls & $\mathrm{Y}$ & $\mathrm{Y}$ & $\mathrm{Y}$ & $\mathrm{Y}$ & $\mathrm{Y}$ & $\mathrm{Y}$ \\
\hline Sample & \multicolumn{6}{|c|}{ All municipalities } \\
\hline Observations & 5,649 & 5,649 & 5,648 & 5,648 & 5,648 & 5,648 \\
\hline \multirow[t]{2}{*}{ Panel B: Mediation } & (1) & $(2)$ & (3) & (4) & $(5)$ & (6) \\
\hline & \multicolumn{2}{|c|}{ Protests 1953} & \multicolumn{2}{|c|}{ SED vote share 1946} & \multicolumn{2}{|c|}{ Turnout 1946} \\
\hline Mean of dep. var & 0.220 & 0.220 & 0.394 & 0.394 & 0.937 & 0.937 \\
\hline \multirow[t]{3}{*}{ Allied } & $0.171^{* * *}$ & $0.146^{* *}$ & $-0.030^{* *}$ & $-0.027^{* *}$ & $-0.016^{* *}$ & -0.008 \\
\hline & $(0.061)$ & $(0.059)$ & $(0.013)$ & $(0.013)$ & $(0.007)$ & $(0.007)$ \\
\hline & {$[0.061]$} & {$[0.058]$} & {$[0.011]$} & {$[0.012]$} & {$[0.006]$} & {$[0.006]$} \\
\hline Bandwidth & $50 \mathrm{~km}$ & $50 \mathrm{~km}$ & $50 \mathrm{~km}$ & $50 \mathrm{~km}$ & $50 \mathrm{~km}$ & $50 \mathrm{~km}$ \\
\hline Forcing variable $f\left(\mathbf{g}_{i}\right)$ & \multicolumn{6}{|c|}{ Linear $\times$ Allied } \\
\hline Border segment FEs & $\mathrm{Y}$ & $\mathrm{Y}$ & $\mathrm{Y}$ & $\mathrm{Y}$ & $\mathrm{Y}$ & $\mathrm{Y}$ \\
\hline Full controls & $\mathrm{Y}$ & $\mathrm{Y}$ & $\mathrm{Y}$ & $\mathrm{Y}$ & $\mathrm{Y}$ & $\mathrm{Y}$ \\
\hline Census 1946 controls & & $\mathrm{Y}$ & & $\mathrm{Y}$ & & $\mathrm{Y}$ \\
\hline Sample & \multicolumn{2}{|c|}{ Pop. $\geq 1,000$} & \multicolumn{4}{|c|}{ All municipalities } \\
\hline Observations & 966 & 966 & 5,649 & 5,648 & 5,649 & 5,648 \\
\hline
\end{tabular}

Notes: Units of observation in Panel A and columns 3-6 of Panel B are all East German municipalities of 1946. Units of observation in columns 1-2 of Panel B are East German municipalities with a population over 1000. Dependent variables in Panel A: $\log$ population, share in agriculture, industry, service and trade, share of females and the protestant share in the population according to the 1946 census in the Soviet occupation zone. Dependent variables in Panel B as in Table 3 (columns 1-2) and Table 4 (columns 3-6). See also notes in respective tables. Controls are all municipality-level variables of Table 1 (Panel B), and latitude / longitude. Census 1946 controls are the dependent variables of Panel A. Regressions in columns 2-6 of Panel A, and columns 3-6 of Panel B are weighted by the eligible voting population. Standard errors clustered at the county-level in parentheses. Conley standard errors in square brackets. ${ }^{* * *} p<0.01,{ }^{* *} p<0.05,{ }^{*} p<0.1$ 


\section{APPENDIX (for online publication)}

\section{A Appendix Figures}

Figure A.1: The Times, June 71945

\section{RUSSIAN MAP OF ZONES \\ OF OCCUPATION}

\section{ALL THURINGIA AND SAXONY IN SOVIET SPHERE}

\section{LARGE AREA IN BRITISH AND U.S. HANDS TO BE GIVEN UP}

\section{BOUNDARIES IN AUSTRIA}

A map of the allied zones of occupation in Germany published in Russian newspapers yesterday indicated that the whole of the German States of Thuringia, Saxony, Mecklenburg, and Anhalt, as well as the Prussian province of Saxony, would fall on-the Russian side of the line of demarcation.

The Moscow announcement has been received with some surprise in London, for, though it is not questioned that the Russian zone is substantially as shown, it is felt that the statement should have been a joint one and that it would have come more fittingly from the Control Council in Berlin.

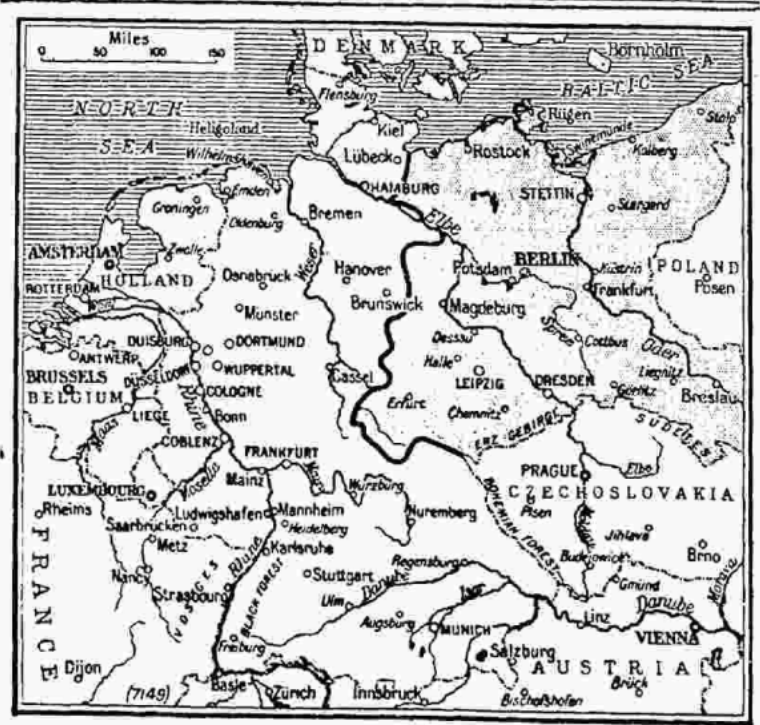

(b)

Notes: Excerpts from The Times newspaper cover from June 71945 showing the cover title and a detailed map of the agreed upon occupation zones. 
Figure A.2: Density of observations around the line of contact - McCrary test

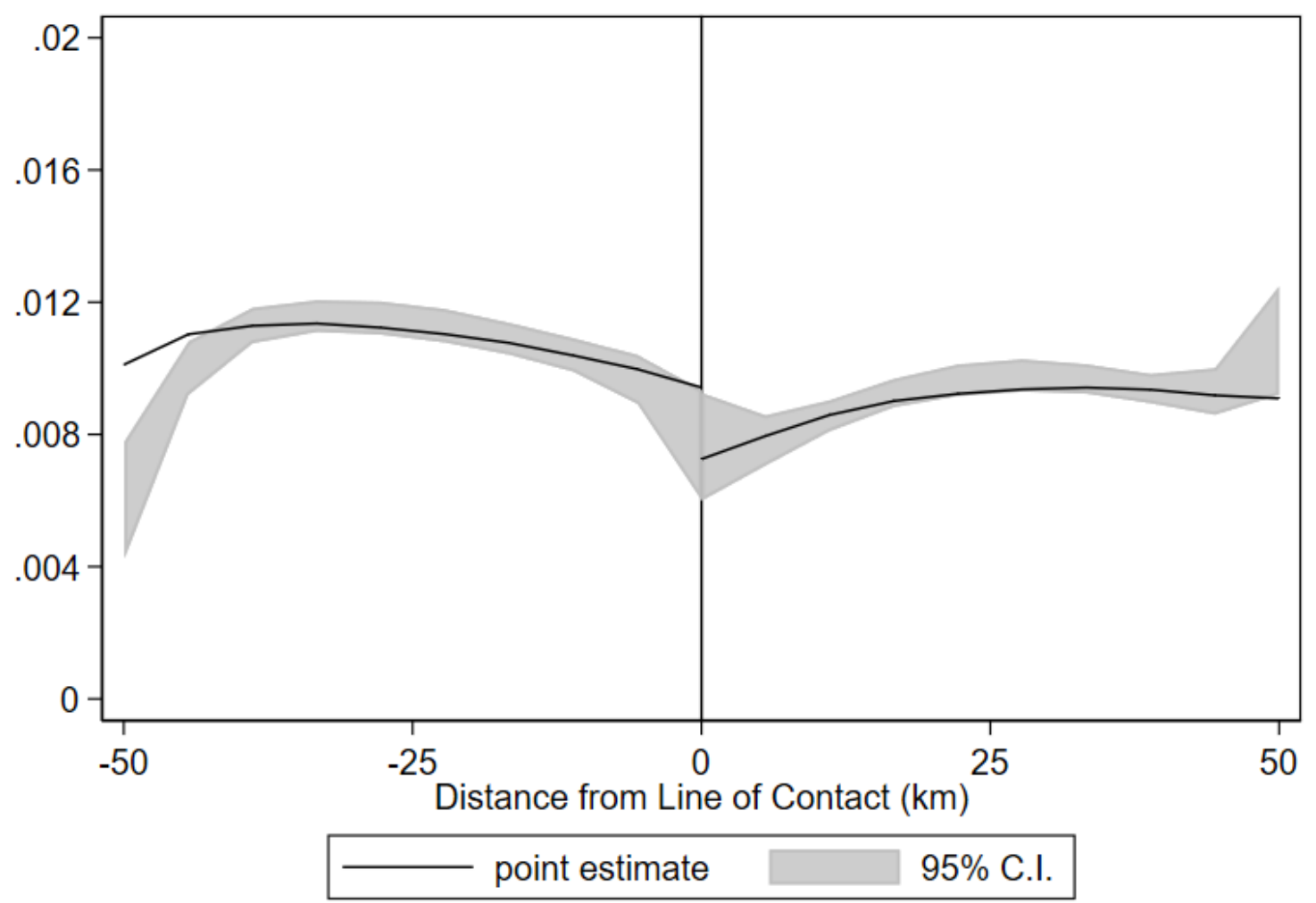

p-value: 0.963

Notes: Figure plots the density of 1946 municipalities around the line of contact using the estimator proposed in Cattaneo et al. (2019). Negative numbers denote the Allied side of the line and positive numbers the Soviet-occupied side, respectively. For estimation the default options described in Cattaneo et al. (2018) are used (local quadratic approximation for local polynomial and cubic approximation for bias correction). 


\section{B Appendix Tables}

Table B1: Allied exposure and 1953 protests - including Schwarzenberg

\begin{tabular}{|c|c|c|c|c|c|}
\hline & $(1)$ & (2) & (3) & (4) & (5) \\
\hline & \multicolumn{5}{|c|}{ Dependent variable: Presence of protest } \\
\hline Mean of dep. variable & $\overline{0.213}$ & 0.213 & 0.213 & 0.213 & 0.213 \\
\hline \multirow[t]{3}{*}{ Allied } & $0.080^{* *}$ & $0.142^{* * *}$ & $0.131^{* *}$ & $0.119^{* * *}$ & $0.130^{* *}$ \\
\hline & $(0.031)$ & $(0.053)$ & $(0.053)$ & $(0.045)$ & $(0.055)$ \\
\hline & [0.025] & {$[0.052]$} & {$[0.051]$} & {$[0.050]$} & {$[0.054]$} \\
\hline Forcing variable $f\left(\mathbf{g}_{i}\right)$ & & Linear & \multicolumn{3}{|c|}{ Linear $\times$ Allied } \\
\hline Border segment FEs & & & & $\mathrm{Y}$ & $\mathrm{Y}$ \\
\hline Full controls & & & & & Y \\
\hline Sample & \multicolumn{5}{|c|}{ Population $\geq 1,000$} \\
\hline Bandwidth & $50 \mathrm{~km}$ & $50 \mathrm{~km}$ & $50 \mathrm{~km}$ & $50 \mathrm{~km}$ & $50 \mathrm{~km}$ \\
\hline Observations & 1,043 & 1,043 & 1,043 & 1,043 & 1,043 \\
\hline
\end{tabular}

Notes: The dependent variable is an indicator for the occurrence of protests during the 1953 uprising. The sample consists of all East German municipalities with a population above 1,000, including municipalities of the initially unoccupied Free Republic of Schwarzenberg These observations are assigned to be Soviet-occupied, as Soviet troops captured the area on June 24, 1945. Border segment FEs consist of ten equally large segments cut along the latitude of municipalities. Controls are all municipality-level variables of Table 1 (Panel B), and latitude / longitude. Standard errors clustered at the county-level in parentheses. Conley standard errors in square brackets. ${ }^{* * *} p<0.01$, ${ }^{* *} p<0.05, * p<0.1$ 
Table B2: Allied exposure and 1946 electoral outcomes - including Schwarzenberg

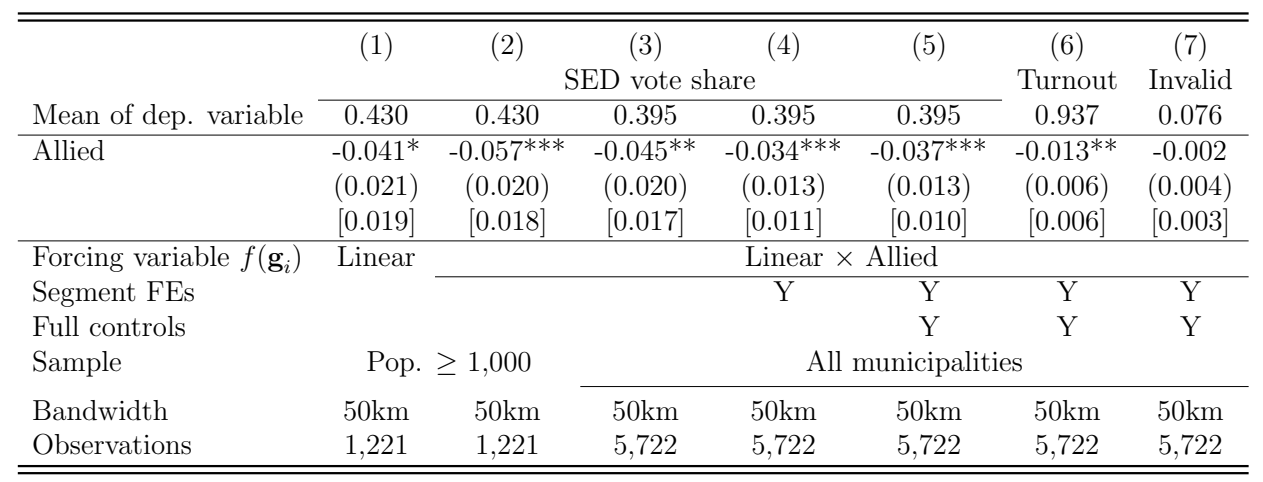

Notes: Units of observation are East German municipalities of 1946, including municipalities of the initially unoccupied Free Republic of Schwarzenberg These observations are assigned to be Sovietoccupied, as Soviet troops captured the area on June 24, 1945. Dependent variable is the vote share of the Socialist Unity Party of Germany (SED) in the 1946 Soviet occupation zone state elections calculated as the share of SED votes among the eligible population. Voter turnout is the share of cast votes (valid and invalid) and invalid denotes the share of invalid votes of the eligible population. Border segment FEs consist of ten equally large segment cut along the latitude of municipalities. Controls are all municipality-level variables of Table 1 (Panel B), and latitude / longitude. Regressions are weighted by the eligible voting population. Standard errors clustered at the county-level in parentheses. Conley standard errors in square brackets. *** $p<0.01$, ** $p<0.05,{ }^{*} p<0.1$ 
Table B3: Allied exposure and 1953 protest - Radio in the American Sector

\begin{tabular}{|c|c|c|c|c|c|c|c|c|}
\hline \multirow[b]{3}{*}{ Mean of dep. variable } & $(1)$ & $(2)$ & $(3)$ & $(4)$ & $(5)$ & $(6)$ & $(7)$ & (8) \\
\hline & \multicolumn{2}{|c|}{ RIAS signal strength } & \multicolumn{6}{|c|}{ Dependent variable: Presence of protest } \\
\hline & 70.222 & 70.222 & 0.220 & 0.220 & 0.220 & 0.220 & 0.220 & 0.220 \\
\hline \multirow[t]{3}{*}{ Allied } & 0.530 & 0.250 & $0.142^{* * *}$ & $0.144^{* * *}$ & $0.169^{* * *}$ & $0.159^{* * *}$ & $0.155^{* *}$ & $0.154^{* *}$ \\
\hline & $(1.151)$ & $(0.857)$ & $(0.050)$ & $(0.050)$ & $(0.061)$ & $(0.060)$ & $(0.061)$ & $(0.061)$ \\
\hline & {$[0.651]$} & {$[0.603]$} & {$[0.057]$} & {$[0.057]$} & {$[0.061]$} & {$[0.061]$} & {$[0.062]$} & {$[0.062]$} \\
\hline \multirow[t]{3}{*}{ RIAS signal strength } & & & 0.003 & 0.015 & -0.019 & & & -0.020 \\
\hline & & & $(0.003)$ & $(0.021)$ & $(0.022)$ & & & $(0.023)$ \\
\hline & & & {$[0.003]$} & {$[0.023]$} & {$[0.026]$} & & & {$[0.025]$} \\
\hline \multirow[t]{3}{*}{ RIAS signal strength ${ }^{2}$} & & & & -0.000 & 0.000 & & & 0.000 \\
\hline & & & & $(0.000)$ & $(0.000)$ & & & $(0.000)$ \\
\hline & & & & {$[0.000]$} & {$[0.000]$} & & & {$[0.000]$} \\
\hline \multirow[t]{3}{*}{ Signal strength (alt.) } & & & & & & $0.001^{*}$ & 0.005 & 0.004 \\
\hline & & & & & & $(0.001)$ & $(0.005)$ & $(0.005)$ \\
\hline & & & & & & {$[0.001]$} & {$[0.005]$} & {$[0.005]$} \\
\hline \multirow[t]{3}{*}{ Signal strength (alt. $)^{2}$} & & & & & & & -0.000 & -0.000 \\
\hline & & & & & & & $(0.000)$ & $(0.000)$ \\
\hline & & & & & & & {$[0.000]$} & {$[0.000]$} \\
\hline \multirow[t]{3}{*}{ Distance to Berlin (km) } & & $-0.078^{* * *}$ & & & $-0.003^{* *}$ & $-0.002^{* *}$ & $-0.002^{* *}$ & $-0.003^{* *}$ \\
\hline & & $(0.028)$ & & & $(0.001)$ & $(0.001)$ & $(0.001)$ & $(0.001)$ \\
\hline & & {$[0.016]$} & & & {$[0.002]$} & {$[0.001]$} & {$[0.001]$} & {$[0.002]$} \\
\hline Forcing variable $f\left(\mathbf{g}_{i}\right)$ & \multicolumn{8}{|c|}{ Linear $\times$ Allied } \\
\hline Border segment FEs & $\mathrm{Y}$ & $\mathrm{Y}$ & $\mathrm{Y}$ & $\mathrm{Y}$ & $\mathrm{Y}$ & $\mathrm{Y}$ & $\mathrm{Y}$ & $\mathrm{Y}$ \\
\hline Full controls & & $\mathrm{Y}$ & & & Y & Y & Y & $\mathrm{Y}$ \\
\hline Sample & & & & Pop. $\geq$ & 1,000 & & & \\
\hline Bandwidth & $50 \mathrm{~km}$ & $50 \mathrm{~km}$ & $50 \mathrm{~km}$ & $50 \mathrm{~km}$ & $50 \mathrm{~km}$ & $50 \mathrm{~km}$ & $50 \mathrm{~km}$ & $50 \mathrm{~km}$ \\
\hline Observations & 968 & 968 & 968 & 968 & 968 & 968 & 968 & 968 \\
\hline
\end{tabular}

Notes: Units of observation are all East German municipalities with a population above 1,000. The dependent variable in columns 1-2 is the signal strength of the Radio in the American Sector (RIAS) and in columns 3-8 an indicator for the occurrence of protests during the 1953 uprising. Protest data and RIAS signal strength at the municipality level from Crabtree et al. (2018). The alternative signal strength indicator stems from 222 towns in East Germany and are merged by nearest neighbour matching. Controls are all municipality-level variables of Table 1 (Panel B), and latitude / longitude. Standard errors clustered at the county-level in parentheses. Conley standard errors in square brackets. ${ }^{* * *} \mathrm{p}<0.01,{ }^{* *} \mathrm{p}<0.05,{ }^{*} \mathrm{p}<0.1$ 
Table B4: Population share by pre- and post-war place of residence in East Germany

\begin{tabular}{|c|c|c|c|c|c|}
\hline \multirow[b]{3}{*}{ Place of residence September 1, 1939} & $(1)$ & $(2)$ & $(3)$ & $(4)$ & $(5)$ \\
\hline & \multicolumn{5}{|c|}{ State of residence October 29, 1946} \\
\hline & Brandenburg & $\begin{array}{l}\text { Mecklenburg- } \\
\text { Vorpommern }\end{array}$ & Saxony & $\begin{array}{l}\text { Saxony- } \\
\text { Anhalt }\end{array}$ & Thuringia \\
\hline \multicolumn{6}{|l|}{ Soviet Occupied Zone } \\
\hline Brandenburg & 0.710 & 0.007 & 0.003 & 0.009 & 0.005 \\
\hline Mecklenburg-Vorpommern & 0.002 & 0.533 & 0.001 & 0.001 & 0.001 \\
\hline Saxony & 0.003 & 0.002 & 0.855 & 0.008 & 0.010 \\
\hline Saxony Anhalt & 0.003 & 0.001 & 0.002 & 0.720 & 0.006 \\
\hline Turingia & 0.001 & 0.001 & 0.002 & 0.005 & 0.739 \\
\hline Berlin & 0.053 & 0.012 & 0.005 & 0.018 & 0.015 \\
\hline Trizone & 0.009 & 0.018 & 0.008 & 0.020 & 0.027 \\
\hline \multicolumn{6}{|l|}{ Former eastern territories of Germany } \\
\hline East Prussia & 0.021 & 0.088 & 0.014 & 0.023 & 0.024 \\
\hline Pommerania (east of river Oder) & 0.028 & 0.159 & 0.003 & 0.013 & 0.008 \\
\hline Brandenburg (east of rivers Oder and Lusatian Neisse) & 0.059 & 0.014 & 0.001 & 0.008 & 0.003 \\
\hline Silesia & 0.048 & 0.027 & 0.075 & 0.062 & 0.066 \\
\hline \multicolumn{6}{|l|}{ Foreign countries } \\
\hline Poland & 0.027 & 0.024 & 0.004 & 0.019 & 0.008 \\
\hline Czechoslovakia & 0.016 & 0.080 & 0.020 & 0.076 & 0.070 \\
\hline Soviet Union & 0.001 & 0.001 & 0.000 & 0.001 & 0.000 \\
\hline Other foreign countries & 0.013 & 0.032 & 0.005 & 0.015 & 0.013 \\
\hline Other & 0.005 & 0.001 & 0.002 & 0.001 & 0.004 \\
\hline
\end{tabular}

Notes: Table shows state of residence on October 20, 1946 by place of residence on September 1, 1939. For children born after September 1, 1939, the place of the residence of the parents is being used. Trizone refers to the American, British and French occupied zones. Other denotes that the 1939 location was not specified. Source: Census of the German Occupied Zone from 1946. 
Table B5: Allied exposure and migration

\begin{tabular}{|c|c|c|c|c|c|c|}
\hline & (1) & (2) & $(3)$ & (4) & $(5)$ & (6) \\
\hline & \multicolumn{6}{|c|}{ Share that lived in same state } \\
\hline Mean of dep. variable & 0.727 & 0.736 & 0.736 & 0.736 & 0.736 & 0.736 \\
\hline \multirow[t]{2}{*}{ Allied } & 0.021 & -0.001 & -0.003 & -0.039 & -0.012 & -0.001 \\
\hline & $(0.018)$ & $(0.029)$ & $(0.028)$ & $(0.058)$ & $(0.041)$ & $(0.038)$ \\
\hline Forcing variable $f\left(\mathbf{g}_{i}\right)$ & & & Linear & \multicolumn{3}{|c|}{ Linear $\times$ Allied } \\
\hline Border segment FEs & & & & & $\bar{Y}$ & $\bar{Y}$ \\
\hline Controls & & & & & & $\mathrm{Y}$ \\
\hline Bandwidth & Full & $50 \mathrm{~km}$ & $50 \mathrm{~km}$ & $50 \mathrm{~km}$ & $50 \mathrm{~km}$ & $50 \mathrm{~km}$ \\
\hline Observations & 178 & 89 & 89 & 89 & 89 & 89 \\
\hline
\end{tabular}

Notes: Units of observation are counties of the GDR of 1946. The dependent variable is the population share that lived in the same state on October 291946 as on September 1 1939. Source: Census of the German Occupied Zone from 1946. Border segment FEs consist of four equally large segments cut along the latitude of districts. Controls are distance to Berlin, distance to the inner German border and latitude / longitude. Robust standard errors in parentheses. ${ }^{* * *} \mathrm{p}<0.01,{ }^{* *}$ $\mathrm{p}<0.05,{ }^{*} \mathrm{p}<0.1$ 


\section{Robustness - 1953 protests}

Figure C.1: 1953 protest result with border segments omitted

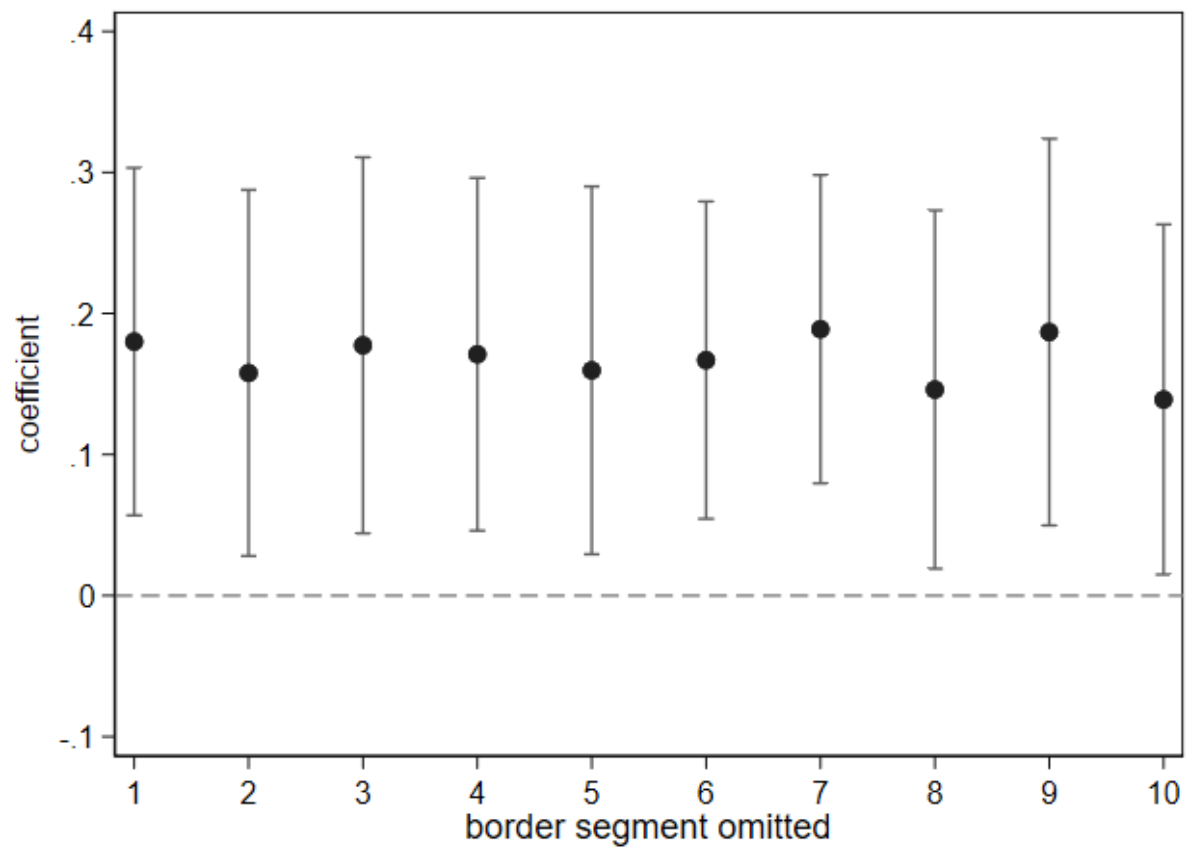

Notes: Figure shows regression estimates corresponding to Table 3 where each of the ten equally large border segments are dropped in turn. Estimates are based on the full specification in column 5. See Table 3 for additional notes. Whiskers show $95 \%$ confidence intervals. 
Figure C.2: 1953 protest results with states omitted

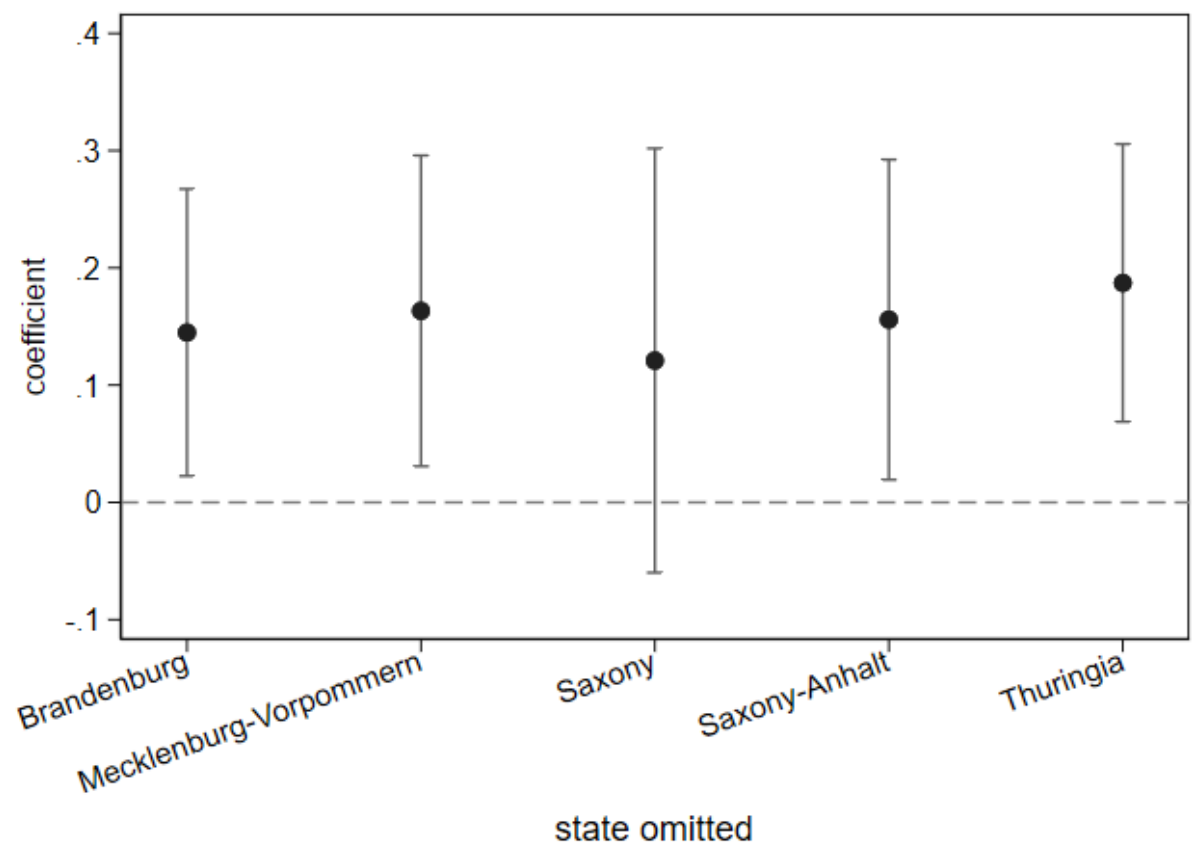

Notes: Figure shows regression estimates corresponding to Table 3 where each of the five states are dropped in turn. Estimates are based on the full specification in column 5. See Table 3 for additional notes. Whiskers show $95 \%$ confidence intervals. 
Figure C.3: 1953 protest result by whether the line of contact is defined by a river

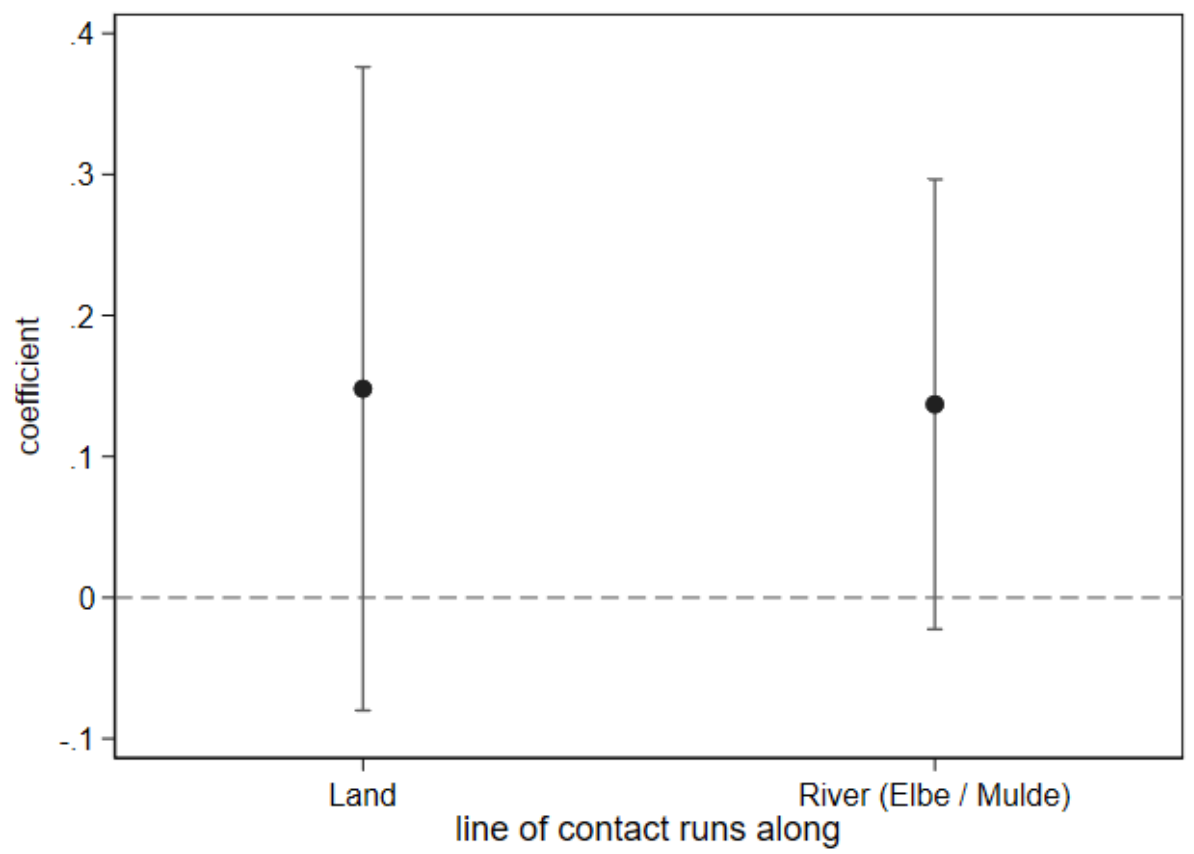

Notes: Figure shows regression estimates corresponding to Table 3 where the sample is split into segments where the line is defined by land or a river. Estimates are based on the full specification in column 5 . See Table 3 for additional notes. Whiskers show $95 \%$ confidence intervals. 
Figure C.4: 1953 protest with varying bandwidth

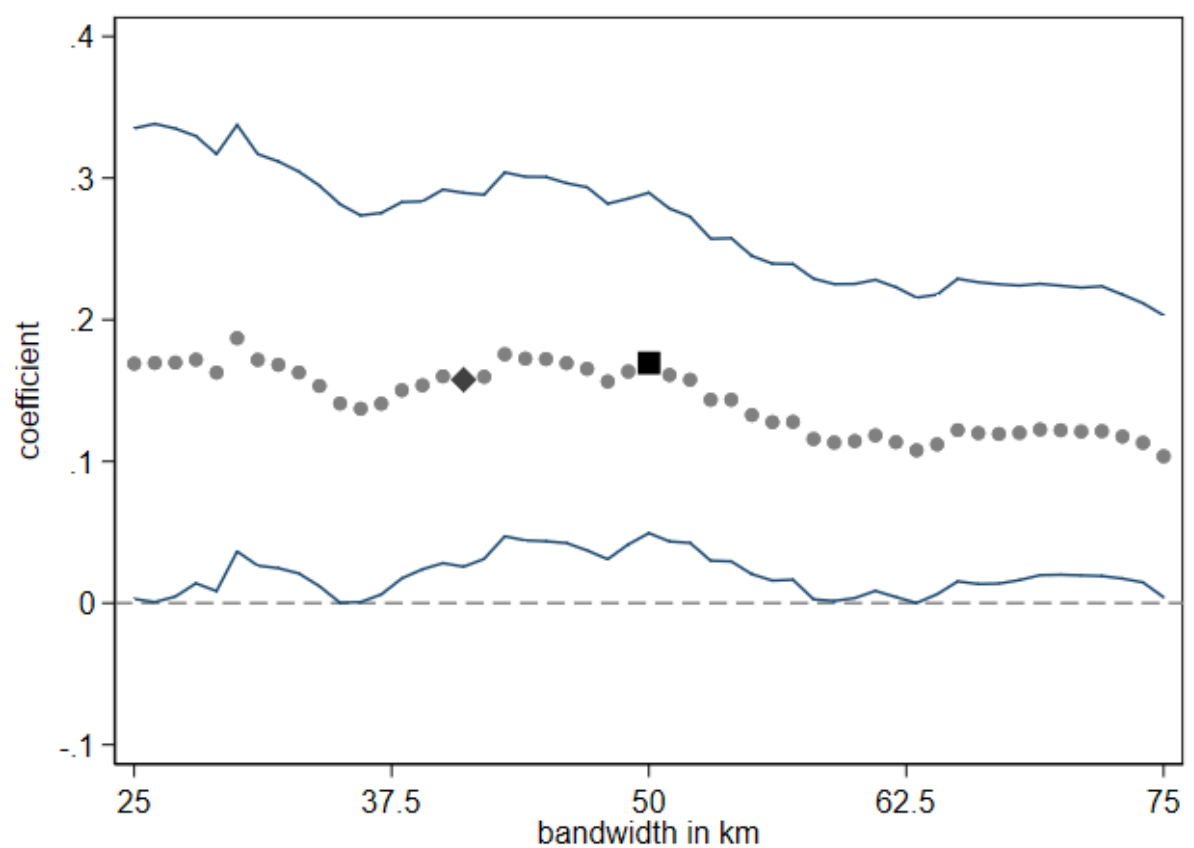

Notes: Figure shows regression estimates of Table 3 with varying bandwidths. Regressions are based on the full specification in column 5 . See Table 3 for additional notes. The black square at 50 $\mathrm{km}$ indicates the coefficient displayed in the table, the dark grey diamond shows the estimate based on the data-driven bandwidth selection using the procedure developed by Calonico et al. (2014). Dark blue lines shows $95 \%$ confidence intervals. 
Figure C.5: 1953 protest results with municipalities dropped in vicinity to the line

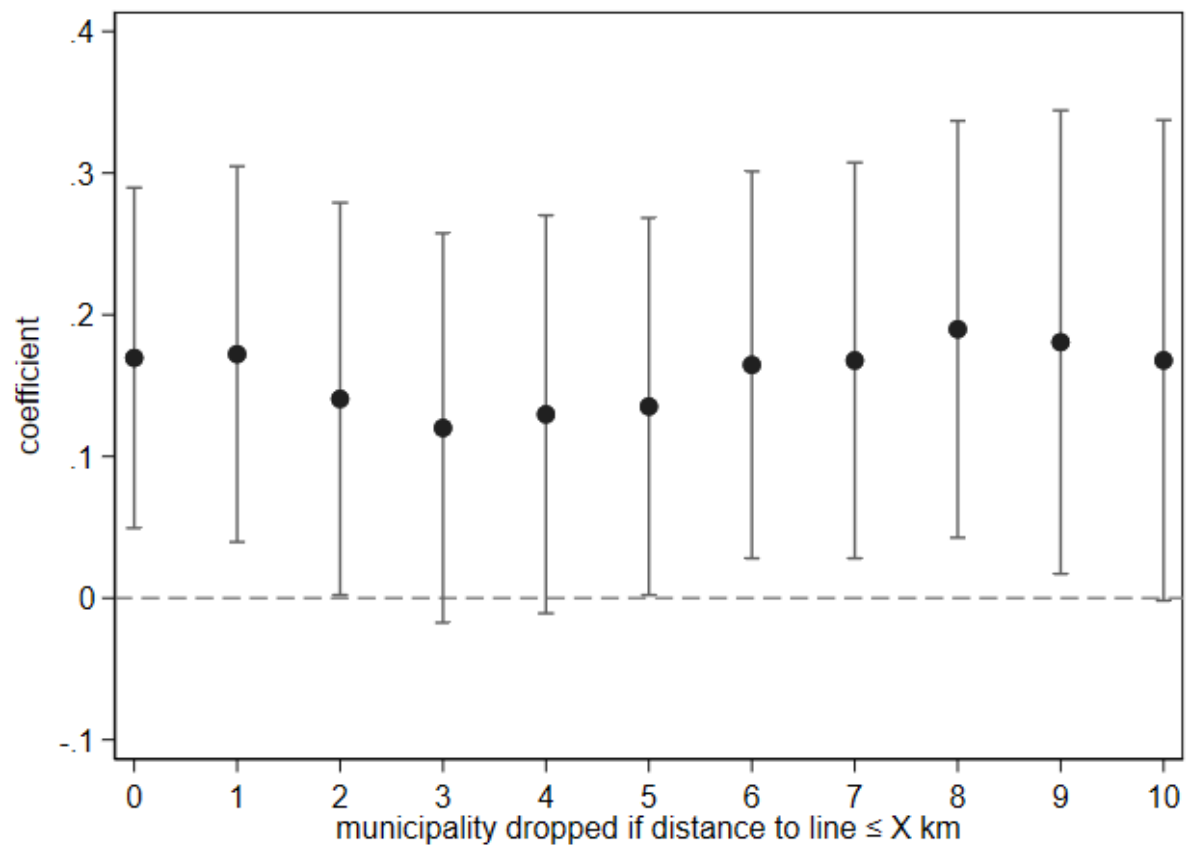

Notes: Figure shows regression estimates corresponding to Table 3 where subsequently municipalities within $\mathrm{x}$ kilometres to the line are dropped (donut $R D D$ ). Estimates are based on the full specification in column 5 . See Table 3 for additional notes. Whiskers show $95 \%$ confidence intervals. 
Figure C.6: 1953 protest result - placebo estimates

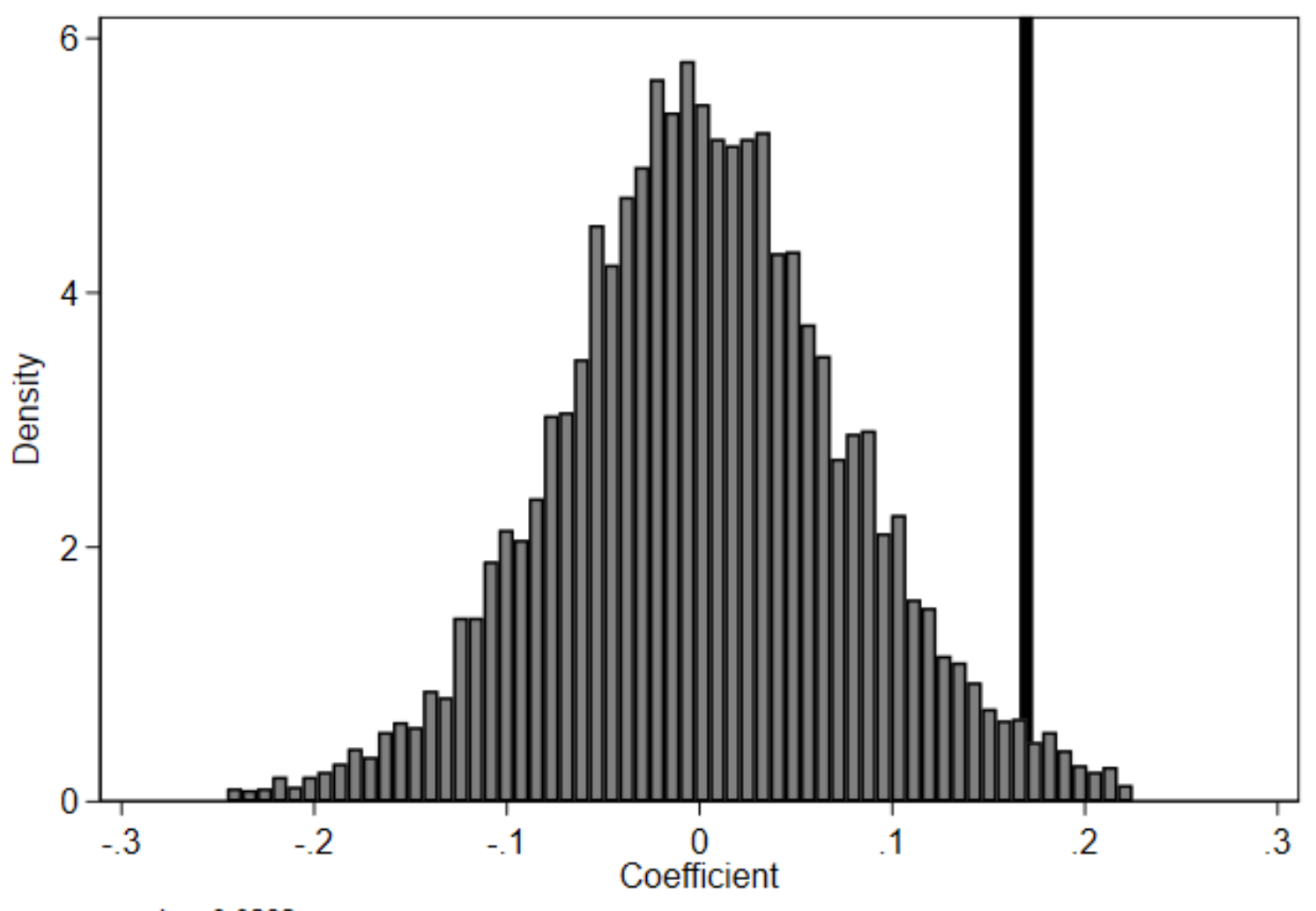

p-value: 0.0282

Notes: Figure shows the distribution of 10,000 coefficients obtained from randomly drawn lines dividing East Germany. The vertical black line indicates the observed coefficient in column 5 of Table 3. See Table 3 for additional notes. $p$-value denotes the share of placebo estimates that are larger than the observed value. For illustration purposes, the lower and upper 1 percent of estimates are not displayed in the histogram. Restriction set on the randomly drawn line is that the Allied and Red Army occupied sides must contain at least 0.25 of observations each. 


\section{Robustness - 1946 elections}

Figure D.1: 1946 election results with border segments omitted
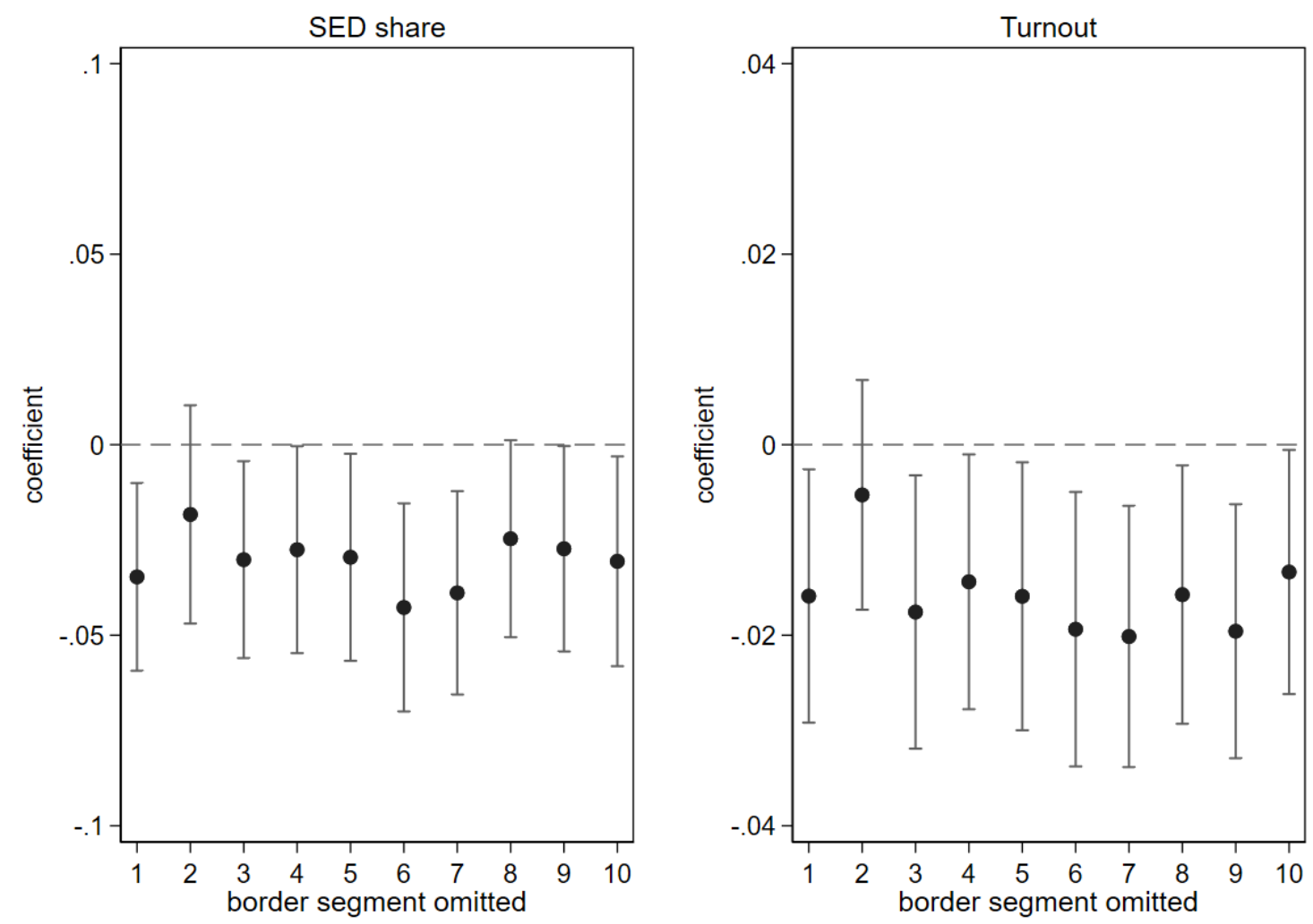

Notes: Figure shows regression estimates corresponding to Table 4 where each of the ten border segments are dropped in turn. Estimates are based on the full specification in columns 5 and 6 , respectively. See Table 4 for additional notes. Whiskers show $95 \%$ confidence intervals. 
Figure D.2: 1946 election results with states omitted
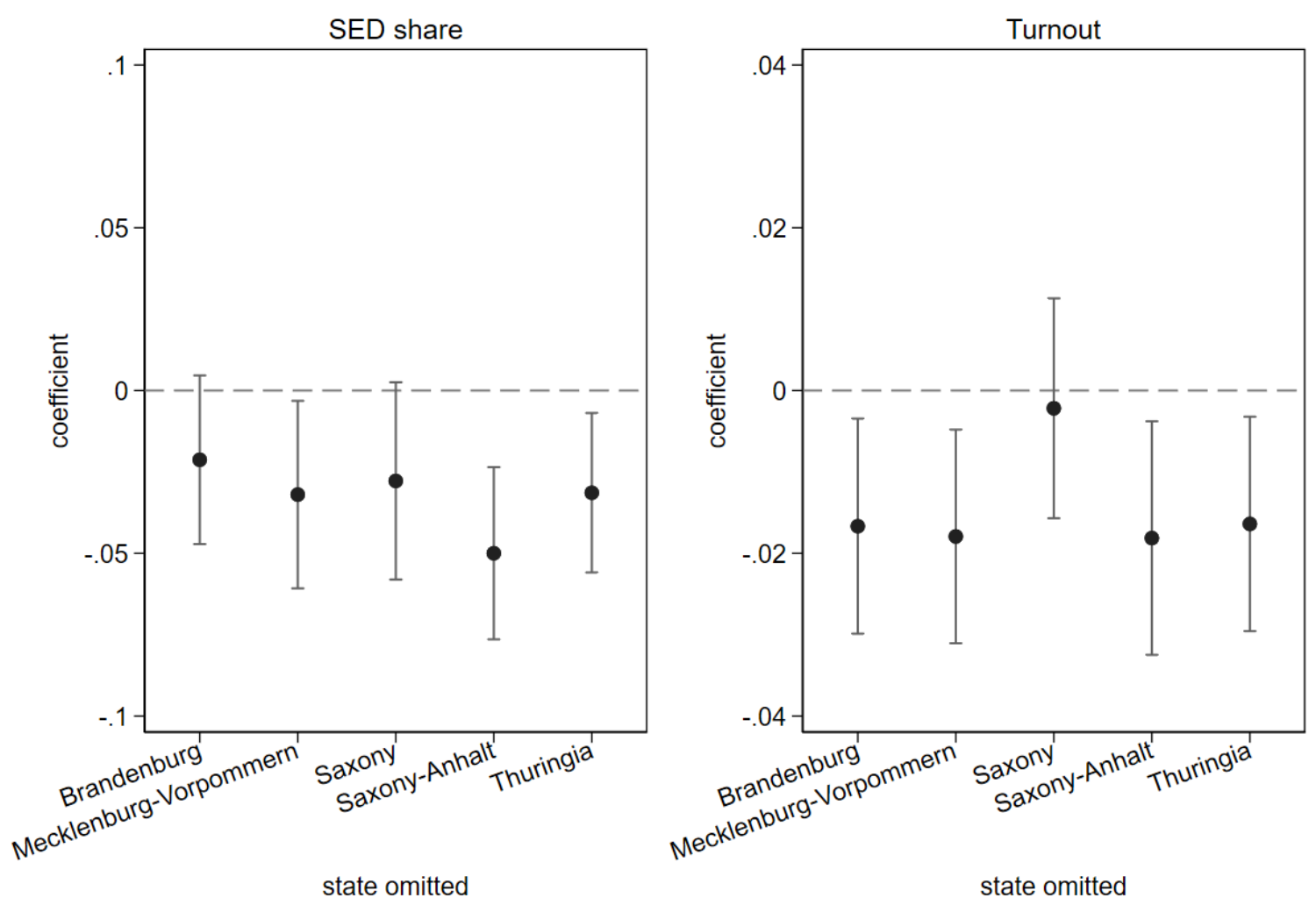

Notes: Figure shows regression estimates corresponding to Table 4 where each of the five states are dropped in turn. Estimates are based on the full specification in columns 5 and 6 , respectively. See Table 4 for additional notes. Whiskers show $95 \%$ confidence intervals. 
Figure D.3: 1946 election result by whether the line is defined by a river
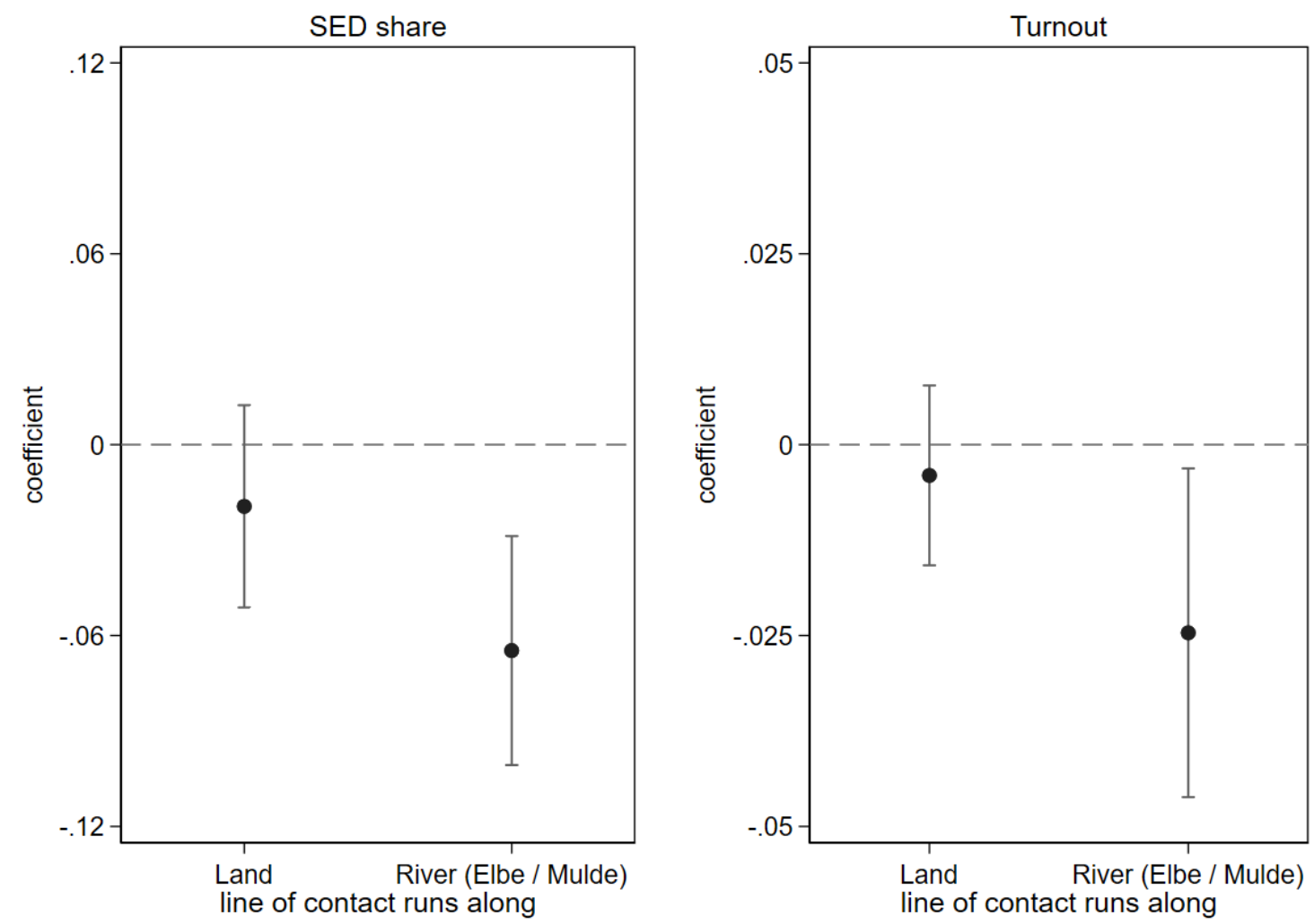

Notes: Figure shows regression estimates corresponding to Table 4 where the sample is split into segments where the line is defined by land or a river. Estimates are based on the full specification in column 5 and 6 , respectively. See Table 4 for additional notes. Whiskers show $95 \%$ confidence intervals. 
Figure D.4: 1946 election results with varying bandwidth
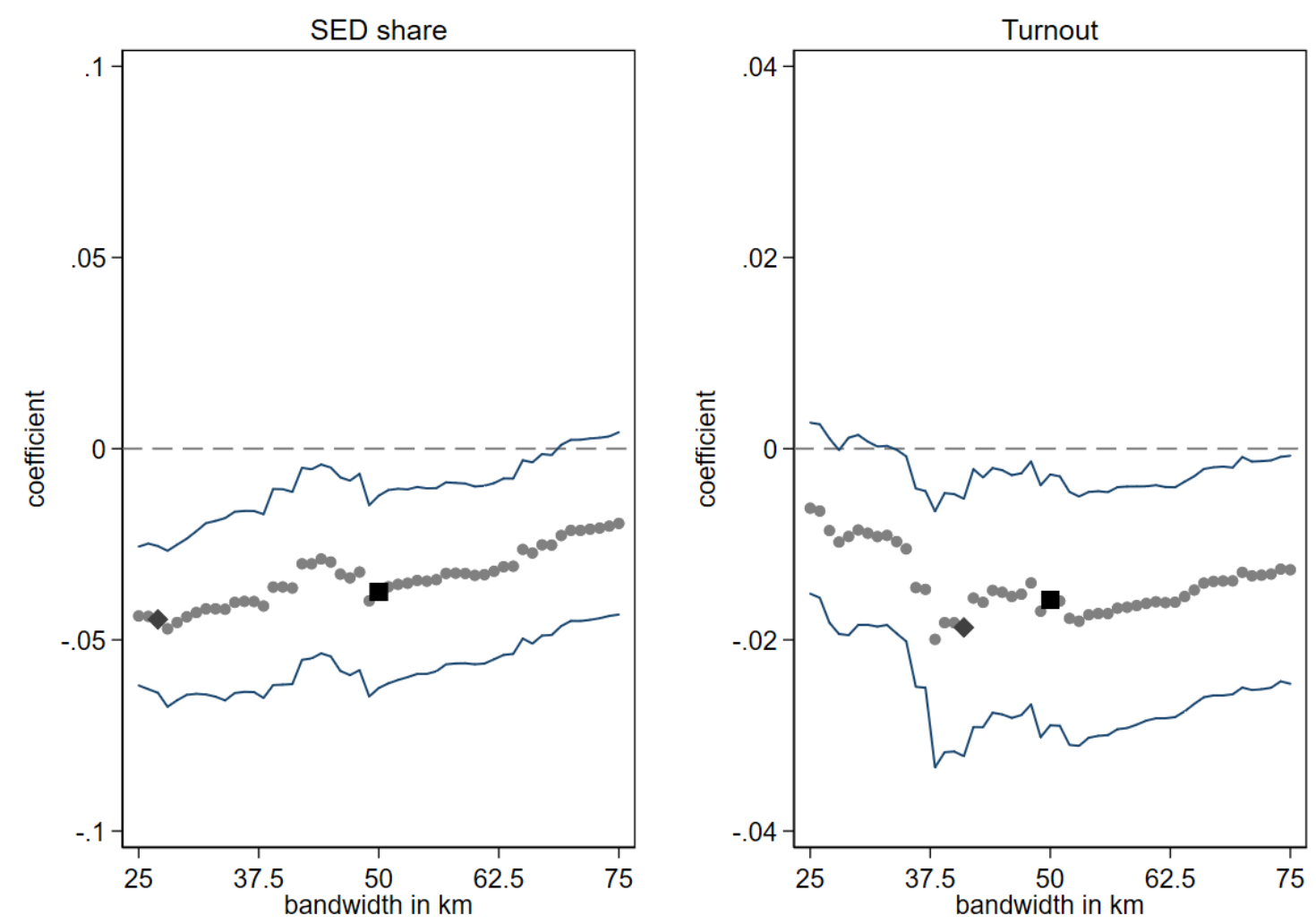

Notes: Figure shows regression estimates of Table 4 with varying bandwidths. Regressions are based on the full specification of columns 5 and 6 , respectively. See Table 4 for additional notes. The black square at $50 \mathrm{~km}$ indicates the coefficient displayed in the table, the dark grey diamond shows the estimate based on the data-driven bandwidth selection using the procedure developed by Calonico et al. (2014). Dark blue lines shows $95 \%$ confidence intervals. 
Figure D.5: 1946 election results with municipalities dropped in vicinity to the line
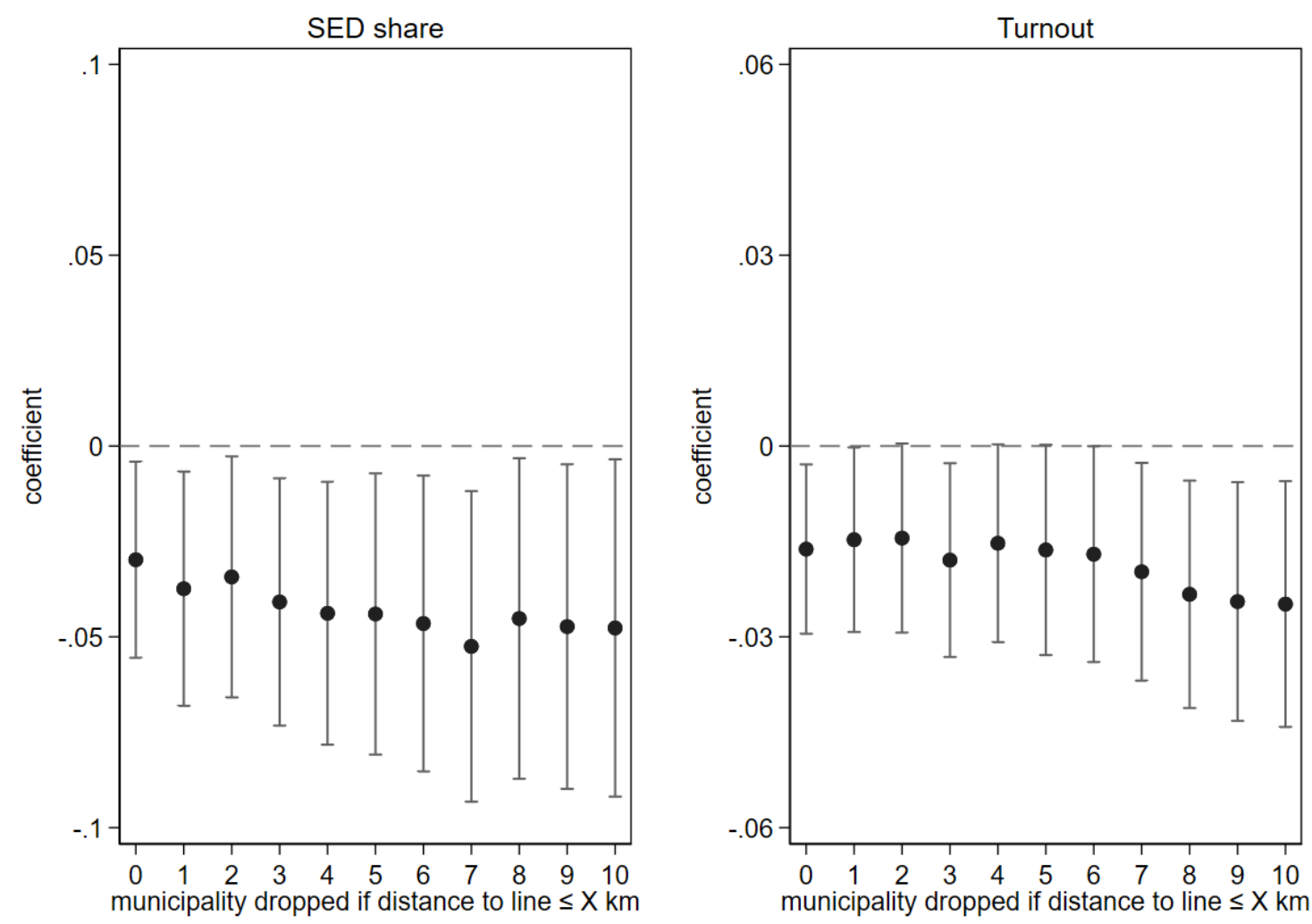

Notes: Figure shows regression estimates corresponding to Table 4 where subsequently municipalities within $\mathrm{x}$ kilometres to the line are dropped (donut $R D D$ ). Estimates are based on the full specification in columns 5 and 6 , respectively. See Table 4 for additional notes. Whiskers show $95 \%$ confidence intervals. 
Figure D.6: 1946 election outcomes - placebo estimates
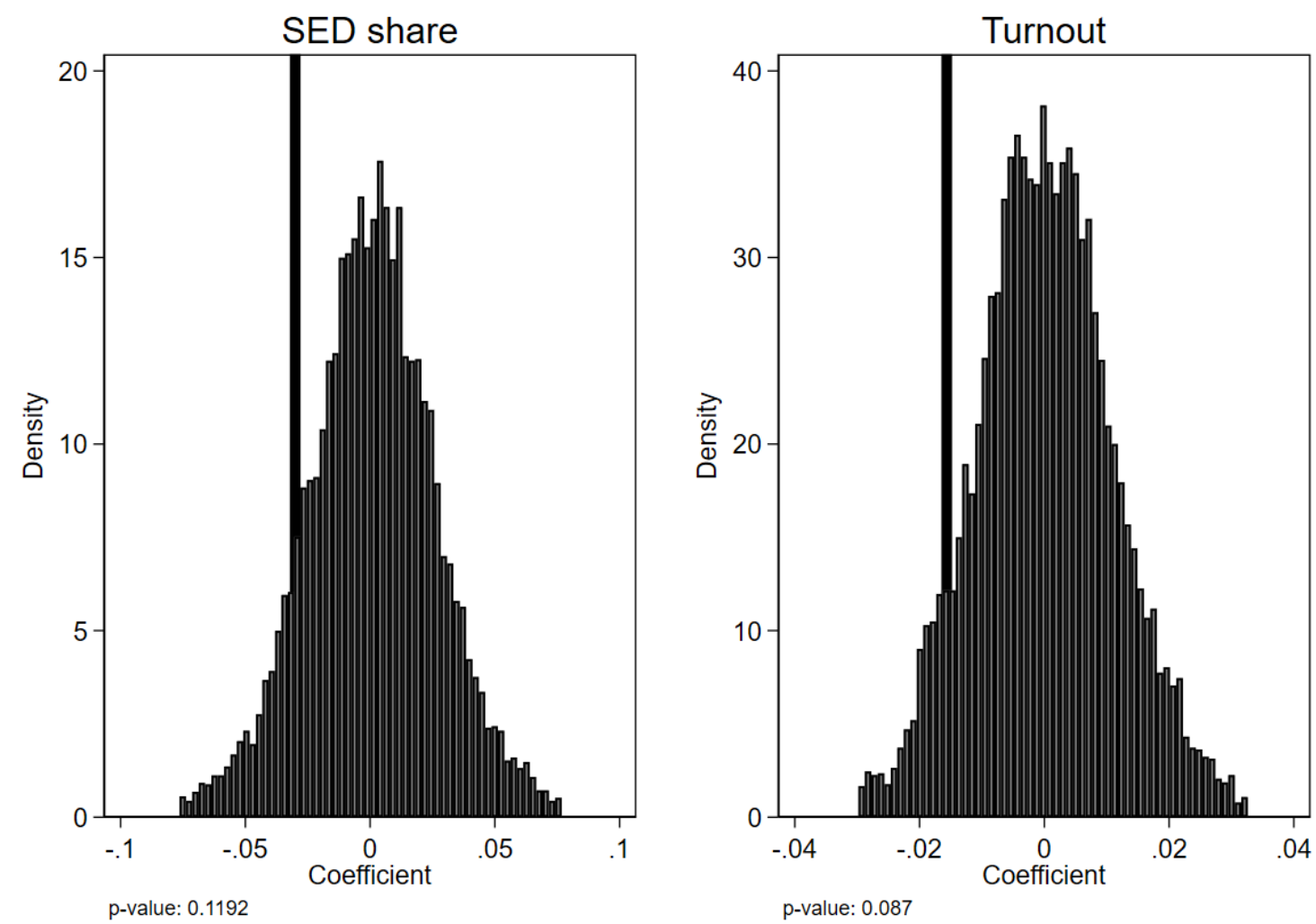

Notes: Figure shows the distribution of 10,000 coefficients obtained from randomly drawn lines dividing East Germany. Vertical black lines indicate the observed coefficients in columns 5 and 6 , respectively, of Table 4 . See table for additional notes. $p$-value denotes the share of placebo estimates that are smaller than the observed values. Restriction set on the randomly drawn line is that the Allied and Red Army occupied sides must contain 0.25 of observations each. 


\section{E Establishing the line of contact}

To identify the line that separates the area occupied by the Western Allies within East Germany at the end of WWII from that occupied by the Red Army, the line of contact, we consulted several sources. We studied the following accounts of the final days of the war: Ambrose (2000); Beevor (2002); Jones (2015); MacDonald (1993); Toland (2003). Particularly helpful was MacDonald (1993), as it not only contains a detailed account of the military moves of the allies, but it also includes a series of maps that document specific operations and an appendix with what appear to be official maps tracking the frontline at various locations and points in time. We extracted information from the daily communiqués by the Supreme Headquarters Allied Expeditionary Force (SHAEF), which provide daily updates on allied operations in the western front. ${ }^{48}$ In some cases, we additionally conducted web searches of specific military units that seemed to have been present in areas where the other sources proved unsatisfactory. ${ }^{49}$ Finally, we also used the following Atlases of the second world war: U.S. Army (1945); Natkiel (1985); Pimlott (1995); Badsey (2000); Gilbert (2008).

For the most part, all sources agree on the location of the line of contact. From north to south, it starts at Wismar on the Baltic and goes down Mecklenburg-Vorpommen (through Schwerin and Ludwiglust) up to Domitz on the Elbe. It then follows the Elbe from Domitz up to Dessau-Roßlau at the intersection with the Mulde and follows the Mulde up to Lunzenau. The last segment (stretching from Lunzenau to a point on the Czech border) was the most challenging to pin down, as it is either not shown in some maps (e.g. Pimlott, 1995; Badsey, 2000) or includes too few reference points, such as cities (e.g. U.S. Army, 1945; Natkiel, 1985). Our reconstruction of this segment is mainly based on the location of the easternmost towns in which the SHAEF communiqués confirmed allied presence. Additionally, we conducted desk research by consulting accounts of contemporary witnesses and other sources such as town websites indicating the identity of the occupying force to pin down the easternmost Allied occupied towns in this segment. From Lunzenau to the Czech border, those towns are Limbach-Oberfrohna, Lichtenstein, Wilkau-Haßlau, Lichteinstein, Auerbach (Vogtland) and Klingenthal.

Having established the location of the line of contact, we assigned the identity of the initial occupying force at the municipality-level. Our main outcomes are all based on this fine-grained assignment of the "treatment". Migration patterns in the 1946 census (Table B4 and Table B5) are only availability at the county-level. As the line of contact played no role in administrative boundaries defined afterwards, a few counties are crossed by the line (predominantly in Saxony, where larger parts of the line are not defined by rivers). We assign these counties to be either Allied or Soviet occupied according to the predominant area or population share assigned to either side. We check the robustness of the results to the exclusion of these "divided" counties.

\footnotetext{
${ }^{48}$ Consulted in March, 2020 at https://lib.byu.edu/collections/eisenhower-communiques

${ }^{49}$ For example, the document "The Mass Surrender of German Troops to the 347th Infantry Regiment on May 6, 1945," consulted in March 2020 at http://87thinfantrydivision.com/tom-stafford/ the-mass-surrender-of-german-troops-to-the-347th-infantry-regiment-on-may-6-1945 was very useful in establishing allied presence in the state of Saxony.
} 